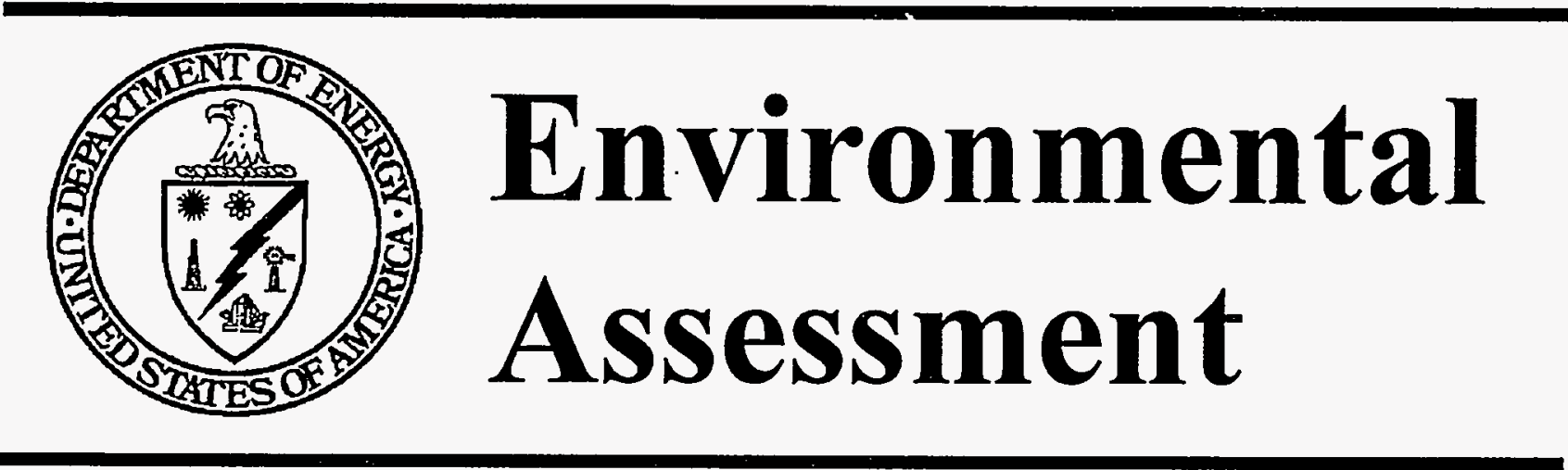

Salvage/Demolition of 200 West Area, 200 East Area and 300 Area Steam Plants, Hanford Site, Richland, Washington 


\title{
ENVIRONMENTAL ASSESSMENT
}

FOR THE

\author{
SALVAGE/DEMOLITION
}

OF

\section{WEST AREA, 200 EAST AREA, AND \\ 300 AREA STEAM PLANTS}

U.S. DEPARTMENT OF ENERGY

$$
\text { RICHLAND, WASHINGTON }
$$

OCTOBER 1996 


\section{DISCLAMMER}

Portions of this document may be illegible in electronic image products. Images are produced from the best available original document. 
Appendices. Additional information necessary to support an understanding of the proposed action, alternatives, and potential impacts is provided.

Comments resulting from review of the environmental assessment by states and tribes or other stakeholders and the response to those comments are included in the appendices. 


\section{METRIC CONVERSION CHART}

Into metric units

Out of metric units

\begin{tabular}{|c|c|c|c|c|c|}
\hline If you know & $\begin{array}{l}\text { Muttiply } \\
\text { by }\end{array}$ & To get & If you know & $\begin{array}{c}\text { Multiply } \\
\text { by }\end{array}$ & To get \\
\hline \multicolumn{3}{|c|}{ Length } & \multicolumn{3}{|c|}{ Length } \\
\hline inches & 25.40 & millimeters & mitlimeters & 0.0393 & inches \\
\hline inches & 2.54 & centimeters & centimeters & $0.393^{\circ}$ & inches \\
\hline feet & 0.3048 & meters & meters & 3.2808 & feet \\
\hline yards & 0.914 & meters & meters & 1.09 & yards \\
\hline miles & 1.609 & kilometers & kilometers & 0.62 & miles \\
\hline \multicolumn{3}{|c|}{ Area } & \multicolumn{3}{|c|}{ Area } \\
\hline $\begin{array}{l}\text { Square } \\
\text { inches }\end{array}$ & 6.4516 & \begin{tabular}{|l} 
square \\
centimeters
\end{tabular} & $\begin{array}{l}\text { square } \\
\text { centimeters }\end{array}$ & 0.155 & $\begin{array}{l}\text { square } \\
\text { inches }\end{array}$ \\
\hline square feet & 0.092 & $\begin{array}{l}\text { square } \\
\text { meters }\end{array}$ & $\begin{array}{l}\text { square } \\
\text { meters }\end{array}$ & 10.7639 & $\begin{array}{l}\text { square } \\
\text { feet }\end{array}$ \\
\hline $\begin{array}{l}\text { Square } \\
\text { yards }\end{array}$ & 0.836 & $\begin{array}{l}\text { square } \\
\text { meters }\end{array}$ & $\begin{array}{l}\text { square } \\
\text { meters }\end{array}$ & 1.20 & $\begin{array}{l}\text { Square } \\
\text { yards }\end{array}$ \\
\hline $\begin{array}{l}\text { square } \\
\text { miles }\end{array}$ & 2.59 & $\begin{array}{l}\text { square } \\
\text { kilometers }\end{array}$ & $\begin{array}{l}\text { square } \\
\text { kilometers }\end{array}$ & 0.39 & $\begin{array}{l}\text { square } \\
\text { miles }\end{array}$ \\
\hline acres & 0.404 & hectares & hectares & 2.471 & acres \\
\hline \multicolumn{3}{|c|}{ Mass (weight) } & \multicolumn{3}{|c|}{ Mass (weight) } \\
\hline ounces & 28.35 & grams & grams & 0.0352 & ounces \\
\hline pounds & 0.453 & kilograms & kilograms & 2.2046 & pounds \\
\hline short ton & 0.907 & metric ton & metric ton & 1.10 & short ton \\
\hline \multicolumn{3}{|c|}{ Volume } & \multicolumn{3}{|c|}{ Volume } \\
\hline $\begin{array}{l}\text { fluid } \\
\text { ounces }\end{array}$ & 29.57 & milliliters & milliliters & 0.03 & $\begin{array}{l}\text { fluid } \\
\text { ounces }\end{array}$ \\
\hline quarts & 0.95 & Titers & Titers & 1.057 & quarts \\
\hline gatlons & 3.79 & Titers & Titers & 0.26 & gallons \\
\hline cubic feet & 0.0283 & $\begin{array}{l}\text { cubic } \\
\text { meters }\end{array}$ & $\begin{array}{l}\text { cubic } \\
\text { meters }\end{array}$ & 35.3147 & cubic feet \\
\hline cubic yards & 0.7645 & $\begin{array}{l}\text { Cubic } \\
\text { meters }\end{array}$ & $\begin{array}{l}\text { cubic } \\
\text { meters }\end{array}$ & 1.308 & $\begin{array}{l}\text { cubic } \\
\text { yards }\end{array}$ \\
\hline \multicolumn{3}{|c|}{ Temperature } & \multicolumn{3}{|c|}{ Temperature } \\
\hline Fahrenheit & $\begin{array}{l}\text { subtract } \\
32 \text { then } \\
\text { multiply } \\
\text { by } 5 / 9 \text { ths }\end{array}$ & Celsius & Celsius & $\begin{array}{l}\text { multiply } \\
\text { by } \\
9 / 5 \text { ths. } \\
\text { then add } \\
32\end{array}$ & Fahrenheit \\
\hline
\end{tabular}

Source: Engineering Unit Conversions, M. R. Lindeburg, PE. . Second Ed., 1990. Professional Publications, Inc., Belmont. California. 


\section{TABLE OF CONTENTS}

PREFACE

METRIC CONVERSION CHART

1.0 PURPOSE AND NEED FOR ACTION ............... . . . . . .

1.1 PURPOSE AND NEED ................... . . . . . . . . . .

1.2 BACKGROUND . . . . . . . . . . . . . . . . . . . 1-1

2.0 DESCRIPTION OF THE PROPOSED ACTION . . . . . . . . . 2-1

2.1 PROPOSED TIMING . . . . . . . . . . . . $2-4$

2.2 ENVIRONMENTAL INFORMATION . . . . . . . . . . . . $2-4$

3.0 ALTERNATIVES TO THE PROPOSED ACTION ............. . . . . . . .

3.1 OTHER ALTERNATIVES $\ldots \ldots \ldots \ldots$

3.2 NO ACTION ALTERNATIVE $\ldots \ldots \ldots$

4.0 AFFECTED ENVIRONMENT . . . . . . . . . . . . . . . 4-1

4.1 GENERAL HANFORD SITE ENVIRONMENT $\ldots \ldots$

4.2 SPECIFIC SITE ENVIRONMENT . . . . . . . . . . . . . . . $4-2$

4.2.1 Soils and Subsurface . . . . . . . . . . . . $4-2$

4.2.2 Hydrology . . . . . . . . . . . . . . . . 4 4-2

4.2 .3 Air Resources . . . . . . . . . . 4-3

4.2.4 Plants and Animals . . . . . . . . . . . . . . .

4.2 .5 Endangered Species . . . . . . . . . . . . . 4-3

4.2 .6 Cultural Resources . . . . . . . . . . . 4-3

5.0 ENVIRONMENTAL IMPACTS . . . . . . . . . . . . 5-1

5.1 SALVAGE/DEMOLITION PHASE $\ldots \ldots \ldots$

5.1.1 Soil or Subsurface Disturbance and the Consequences . . 5-1

5.1.2 Liquid Discharges to the Groundwater or Surface Waters and the Consequences ............. 5-1

5.1.3 Gaseous, Particulate, or Thermal Discharges to the Air and the Consequences ....... 5-1

5.1.4 Radionuclide Releases or Direct Radiation Exposure and the Consequences ............. 5-2

5.1.5 Nonhazardous Solid Waste Generated and the Consequences ............. 5-2

5.1.6 Hazardous or Dangerous Waste Generated and the Consequences ........... . . 5-2

5.1.7 Hazardous Substances Present and the consequences . . 5-2

5.1.8 Any Disturbance to Previously Undeveloped Areas and

5.1.9 Consumption or Commitment of Nonrenewable Resources . . . . . . . . 5-3

5.1 .10 Effects on Cultural Resources . . . . . . 5-3

5.1.11 Effects on Federal1y or State Listed, Proposed or
Candidate. Threatened or Endangered Species.

5.1.12 Effects on any Floodplain or Wetland . . . . . . 5-4 
5.1.13 Effects on any Wild and Scenic River. State or Federal

5.1.14 Reasonably Foreseeable Accidents Considered and the Effects

5.2 SOCIOECONOMIC IMPACTS

........... . . . . . 5-4

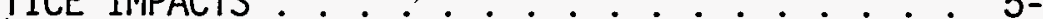

CUMULATIVE IMPACTS

5.5 IMPACTS FROM ALTERNATIVES . . . . . . . . $5-5$

5.5.1 Implementation of Alternatives . . . . . . . 5-5

5.5.2 Implementation of the No Action Alternative . . . . 5-5

6.0 PERMITS AND REgULATORY REQUIREMENTS . . . . . . . . . . . . 6-1

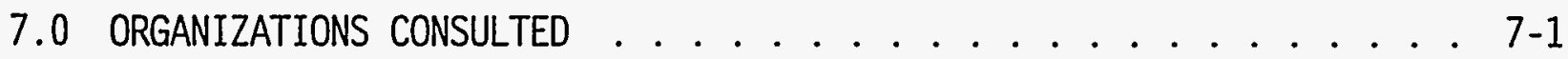

8.0 REFERENCES ...................... . . . . . . . .

\section{APPENDICES}

A BIOLOGICAL REVIEWS .................. APP A-1

B CULTURAL RESOURCES REVIEWS AND CORRESPONDENCE ........ APP B-1

\section{LIST OF FIGURES}

1 Hanford Site Map . . . . . . . . . . . . . . 2-6

2200 West Area Map . . . . . . . . . . . . . . . 2-7

3200 East Area Map . . . . . . . . . . . . . . 2-8

4300 Area Map .................. 2. . . . . . . . . 


\subsection{PURPOSE AND NEED FOR ACTION}

The following sections describe the purpose and need and provide background information concerning this environmental assessment (EA).

\subsection{PURPOSE AND NEED. The underlying purpose and need for the agency to take the proposed action.}

The U.S. Department of Energy, Richland Operations Office (RL) needs to reduce costs of future surveillance and maintenance for the 200 West Area Steam Plant, and avoid future surveillance and maintenance costs for the 200 East Area and 300 Area Steam Plants.

\subsection{BACKGROUND. BACKGROUND information on the purpose and need, that led to the need for action.}

The transition of the Hanford Site mission from defense production to a restoration mission. has reduced the large demand for steam required to support defense operations. The 200 West Area Steam Plant was shut down in fiscal year (FY) 1995 and is currently in surveillance and maintenance awaiting. decommissioning.. The estimated annual cost for access controls and surveillance and maintenance of the steam plants would escalate over time as the facilities deteriorate. The 200 East Area and 300 Area Steam Plants are currently in operation and are expected to be shut down in the near future.

The U.S. Department of Energy - Site Infrastructure Division needs to eliminate costly access controls, surveillance and maintenance activities associated with the deactivation of infrastructure and general purpose facilities. 
The proposed action involves the salvage and demolition of the 200 West Area, 200 East Area, and 300 Area steam plants and their associated steam distribution piping, equipment, and ancillary facilities. Activities include the salvaging and recycling of all materials, wastes, and equipment where feasible, with waste minimization efforts utilized. The existing coal storage yards of each steam plant would provide adequate space as lay down yards to store equipment and material during salvaging activities. A11 areas within the proposed action are previously disturbed industrial areas. It is planned to remove all foundation and concrete footings and return the areas to ground level for potential. reuse. Waste minimization practices would be in place to keep wastes at a minimum.

The three steam plants have similar support buildings and structures. The 200 West Area and 200 East Area powerhouses have very similar building dimensions, while the 300 Area powerhouse is somewhat smaller in size. The specific facilities to be salvaged and demolished in the three areas include:

284-West ( 4 coal boilers), 284-East ( 5 coal boilers \& 1 oil package boiler), and 384 ( 3 coal boilers, 2 oil boilers, \& 1 oil package boiler) powerhouses

- baghouse complexes, coal crushers and transfer houses

- coal handling conveyor systems with track hoppers

- coal storage pits and salt-dissolving pits

- ash sluicing pits and ash disposal basins

- 2710-W and 2710-E coat handler sheds

- fuel oil storage tanks

- smokestacks

aboveground steam distribution system connecting the three powerhouses to various production and office facilities and between the 200 West Area and the 200 East Area powerhouses. 
All areas of the powerhouses and associated facilities are on disturbed ground. The 200 East Area Steam Plant is almost. identical to the 200 West Area Steam Plant. The following are the approximate dimensions of the 200 West Area Steam Plant:

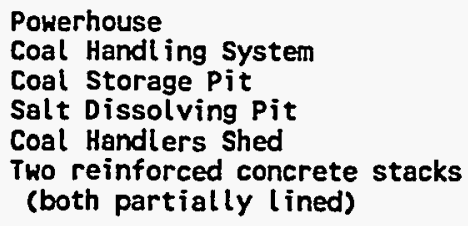

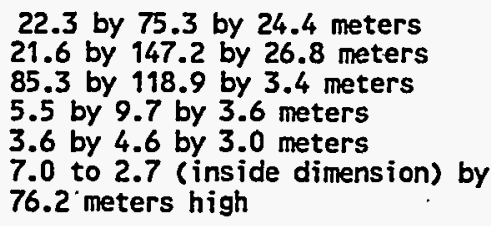

\author{
73 by 247 by 80 feet \\ 71 by 483 by 88 feet \\ 280 by 390 by 11 feet \\ 18 by 32 by 12 feet \\ 12 by 15 by 10 feet \\ 23 to 9 (inside dimension) by \\ 250 feet high
}

The following are the approximate dimensions of the 300 Area Powerhouse:

Powerhouse

90 by 180 by 80 feet

The building footprint for the 284-West Area Powerhouse is about 2520 square meters $(27,132$ square feet): for the 284-East Powerhouse about 3067 square meters (33.015 square feet); and for the 384 Powerhouse about 1594 square meters (17,159 square feet).

The proposed action would occur in areas on the Hanford Site, located in southeastern Washington State (Figure 1). The 200 West Area Steam Plant is in the 200 West Area and located about 48 kilometers (30 mi ies) northwest of the city of Richland (Figure 2). The 200 East Area Steam Plant is in the 200 East Area and located about 40 kilometers ( 25 miles) north of the city limits of Richland (Figure 3). The 300 Area Steam Plant is in the 300 Area and located approximately 5 kilometers ( 3 miles) north of the city limits of Richland (Figure 4). The 0.609 meter (24 inches) diameter, fiberglass insulated steam pipeline between the 284-West and 284-East Powerhouses runs approximately 8 kilometers ( 5 miles) directly between the 200 West and 200 East Areas. The steam distribution pipelines between the 284-West Powerhouse and its associated support facilities runs approximately 8 kilometers ( 5 mi les). between 284-East Powerhouse and its support facilities runs about 6.5 kilometers ( 4 miles), and between the 384 Powerhouse and its support facilities runs about 5 kilometers ( 3 miles).

The proposed work consists of the complete dismantling and removal of all building structures, equipment, and miscellaneous items of the mentioned facilities. Activities include:

Remove asbestos-containing materials and all hazardous materials. The following are the estimated amounts of asbestos-containing materials in the 200 West Steam Plant:

$\begin{array}{lr}\text { Steam plant pipe insulation } & 74 \text { cubic meters } \\ \text { Steam distribution insulation } 266 \text { cubic meters } \\ \text { Transite siding } & 20 \text { cubic meters } \\ \text { Roofing } & 127 \text { cubic meters } \\ \text { Fire brick mortar } & 96 \text { cubic meters } \\ \text { Floor tile } & 1 \text { cubic meter }\end{array}$

2600 cubic feet 9400 cubic feet 700 cubic feet 4500 cubic feet 3400 cubic feet

27 cubic feet 
The following are the estimated amounts of asbestos-containing materials in the 200 East Steam Plant:

$\begin{array}{lrr}\text { Steam plant pipe insulation } & 93 \text { cubic meters } & 3300 \text { cubic feet } \\ \text { Steam distribution insulation } & 161 \text { cubic meters } & 5700 \text { cubic feet } \\ \text { Transite siding } & 25 \text { cubic meters } & 900 \text { cubic feet } \\ \text { Roofing } & 159 \text { cubic meters } & 5600 \text { cubic feet } \\ \text { Fire brick mortar } & 122 \text { cubic meters } & 4300 \text { cubic feet } \\ \text { Floor tile } & 1 \text { cubic meter } & 34 \text { cubic feet }\end{array}$

The following are the estimated amounts of asbestos-containing materials in the 300 Area Steam Plant:

$\begin{array}{llr}\text { Steam plant pipe insulation } & 45 \text { cubic meters } & 1600 \text { cubic feet } \\ \text { Steam distribution insulation } & 40 \text { cubic meters } & 1400 \text { cubic feet } \\ \text { Transite siding } & 11 \text { cubic meters } & 400 \text { cubic feet } \\ \text { Roofing } & 79 \text { cubic meters } & 2800 \text { cubic feet } \\ \text { Fire brick mortar } & 59 \text { cubic meters } & 2100 \text { cubic feet } \\ \text { Floor tile } & .5 \text { cubic meter } & 17 \text { cubic feet }\end{array}$

In addition. smal1 amounts of lead (mostly lead paint) and possibly Polybromated biphenyls (PCB) have been identified in the steam plants. The only PCBs that may be present are contained in the light ballasts. The 300 Area Steam Plant may have \#6 fuel oil in the soil below the 017 storage tank if it has leaked. No radiological hazards are known to exist in the areas of building foundations that will be disturbed during demolition. If there are any residual amounts of these environmentaliy sensitive materials found present at any of the steam plants during the proposed action, they would be removed before demolition activities take place.

Remove equipment and material for reuse/salvage, including the above ground steam and compressed air distribution piping and the support poles holding them. Waste minimization practices would be in place to keep wastes at a minimum.

- Dismantle and remove all buildings and structures. This would be accomplished with wrecking balls, excavators, implosions or other techniques.

- Remove the foundations and retaining wal7s of the structures. This would involve excavations of up to 6 meters (20 feet) in depth for each of the powerhouse structures and 2 meters ( 6 feet) for steam line support poles. If any hazardous materials are found during excavation, they would be dealt with in a manner acceptable to the relevant regulatory agency. If cultural features or artifacts are encountered, work in the vicinity of the discovery would stop and the appropriate cultural resource staff would be notified. 
- Remove rubble from steam plants with the following estimated volumes:

200 West Steam Plant 200 East Steam Plant

300 Area Steam Plant
765 cubic meters

772 cubic meters
390 cubic meters
10,000 cubic yards

10,100 cubic yards

5,100 cubic yards

These estimated volumes of rubble would be disposed of in an acceptable disposal facility.

- Fill foundation voids with fill and cover with 15 centimeters ( 6 inches) of gravel and level to match surrounding grade. Some fill material for the 200 West Area and 200 East Area Steam Plants would come from borrow Pit \#4. located between the 200 West and 200 East Areas. Some fil1 material for the 300 Area Steam Plant would come from borrow Pit \#9, located about 5 kilometers ( 3 miles) north of the 300 Area.

\subsection{PROPOSED TIMING. Timing or schedule of the proposed action (including phasing, if applicable).}

The proposed action would be accomplished in a phased approach. The facilities that have not been shut down would be shut down and secured. Preliminary. deactivation activities would remove major combustibles, drain liquids, permanently isolate all influent/effluent lines, and isolate all electrical power. The 200 West Area Steam Plant is already deactivated and currently in the isolated surveillance and maintenance phase. The 200 East Area and 300 Area Steam Plants would be shut down and placed in the surveillance and maintenance phase. Then salvage and demolition of all three steam plants would begin. The actual salvage/demolition phase of all three steam plants concurrently would last about 16 to 18 months.

The steam pipeline between the 200 West and 200 East Areas would be removed, as well as the steam distribution piping between the steam plants and the facilities these feed. Because the demolition of the steam plants and the steam distribution pipelines would not occur for more than a year, biological survey data would be reconfirmed prior to initiation of the 'salvage and demolition phase of the applicable areas.

\subsection{ENVIRONMENTAL INFORMATION. Other environmental information that has been prepared, or will be prepared, directly related to the proposed action.}

All three steam plants are located within existing operable units (OU) pursuant to the Comprehensive Environmental Response, Compensation. and Liability Act (CERCLA) of 1980. The ash pits and sluice pits for each of the three steam plants of the proposed action would be managed in conjunction with each respective 0U. Following the salvage and demolition of the three steam plants, the grounds of the facilities of the proposed action would be leveled to grade with fill material. If there is any hazardous or radioactive contamination found in the soils during excavation of the foundations to buildings or at the base of the steam distribution system poles, the contaminated soils would be covered with clean soil and left in place for remediation of the OU. Any contamination would be dealt with in a manner 
acceptable to the relevant regulatory agency. At the present time, closure plans for these OUs have not been developed.

Issues surrounding the historical and cultural significance of the three powerhouses have been discussed between DCE-RL and the State Historic Preservation Officer (SHPO) within the Office of Archaeology and Historic Preservation (OAHP) for Washington State. Details of those issues are discussed in Section 4.2.6. 


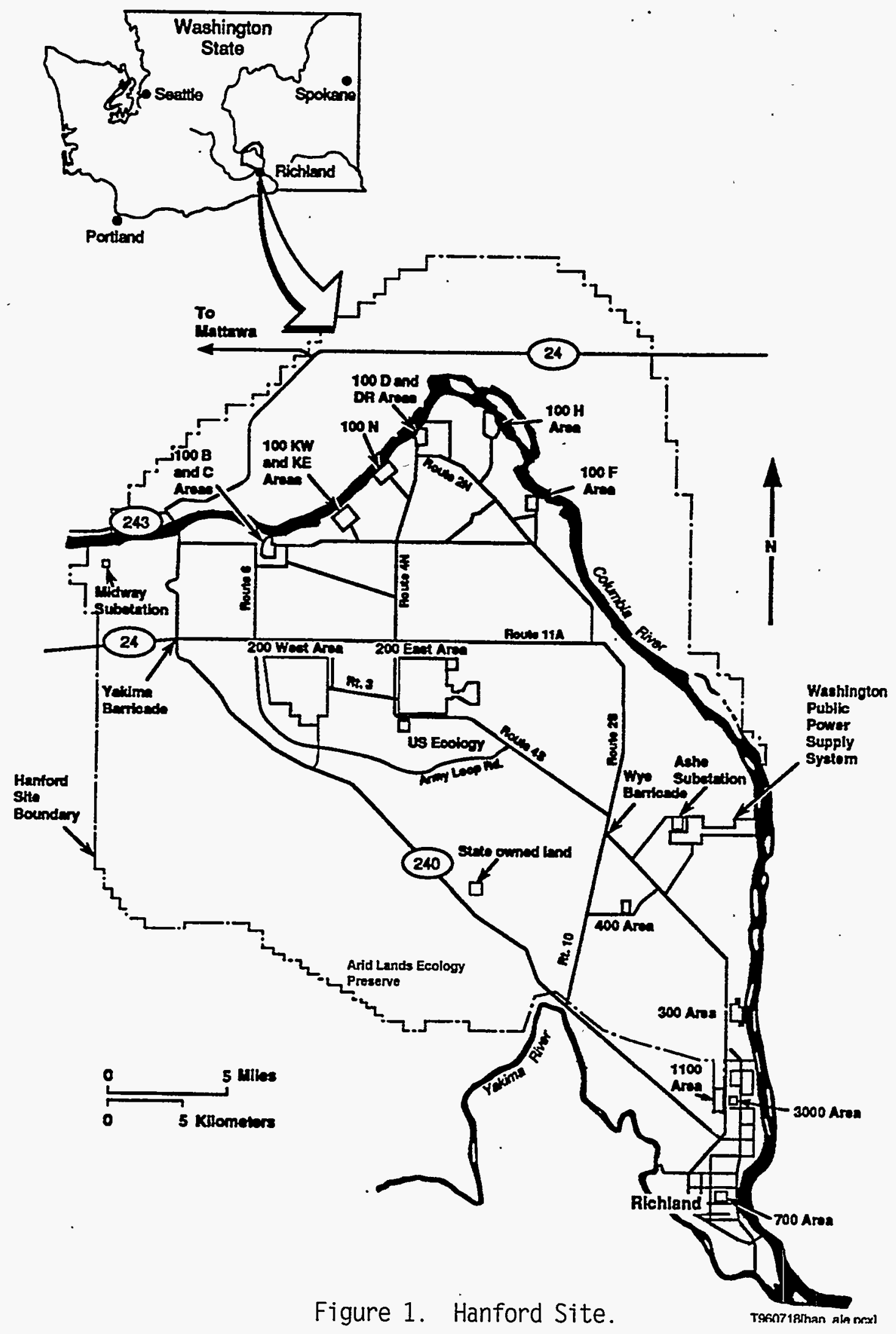




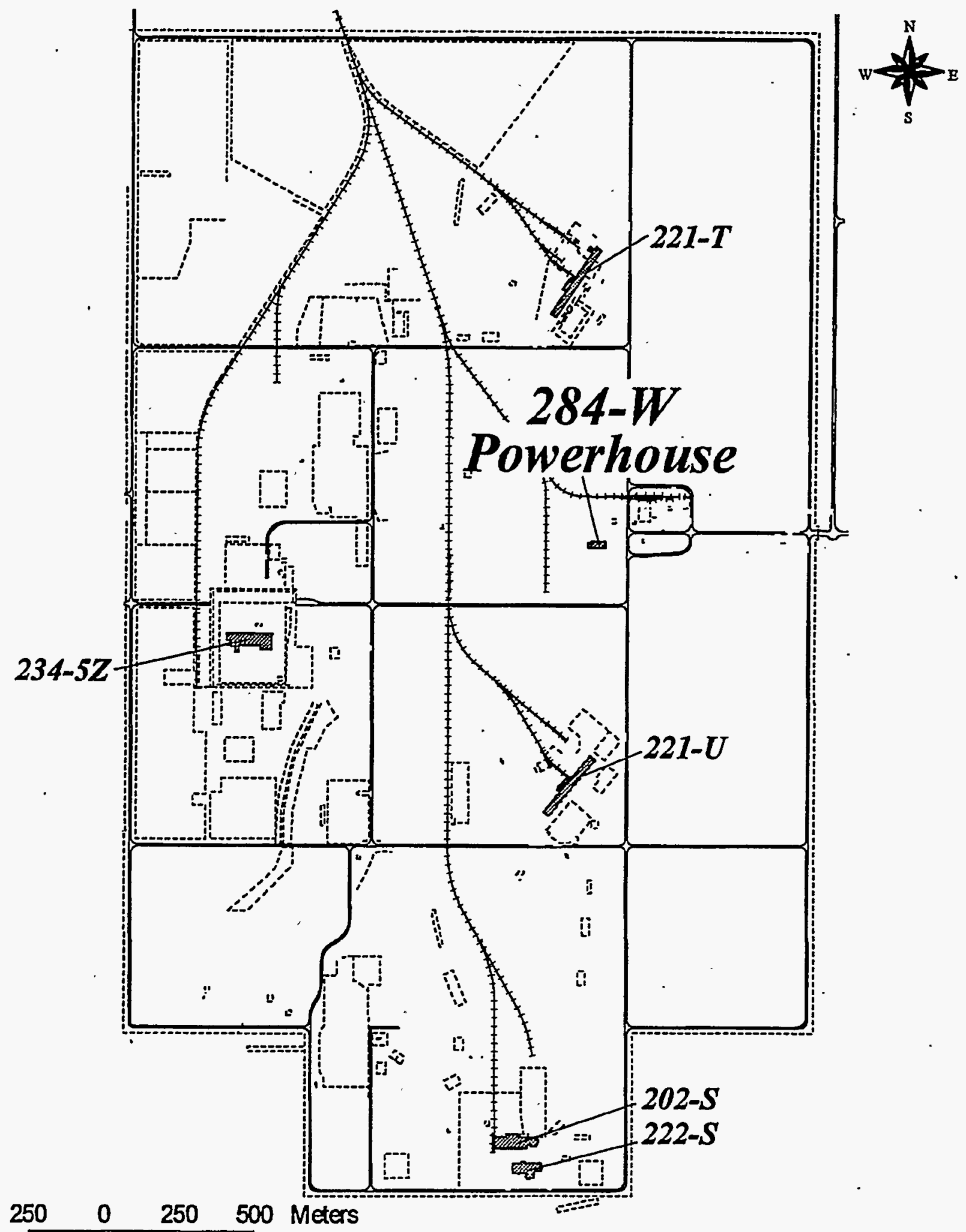

Figure 2. 200 West Area. 


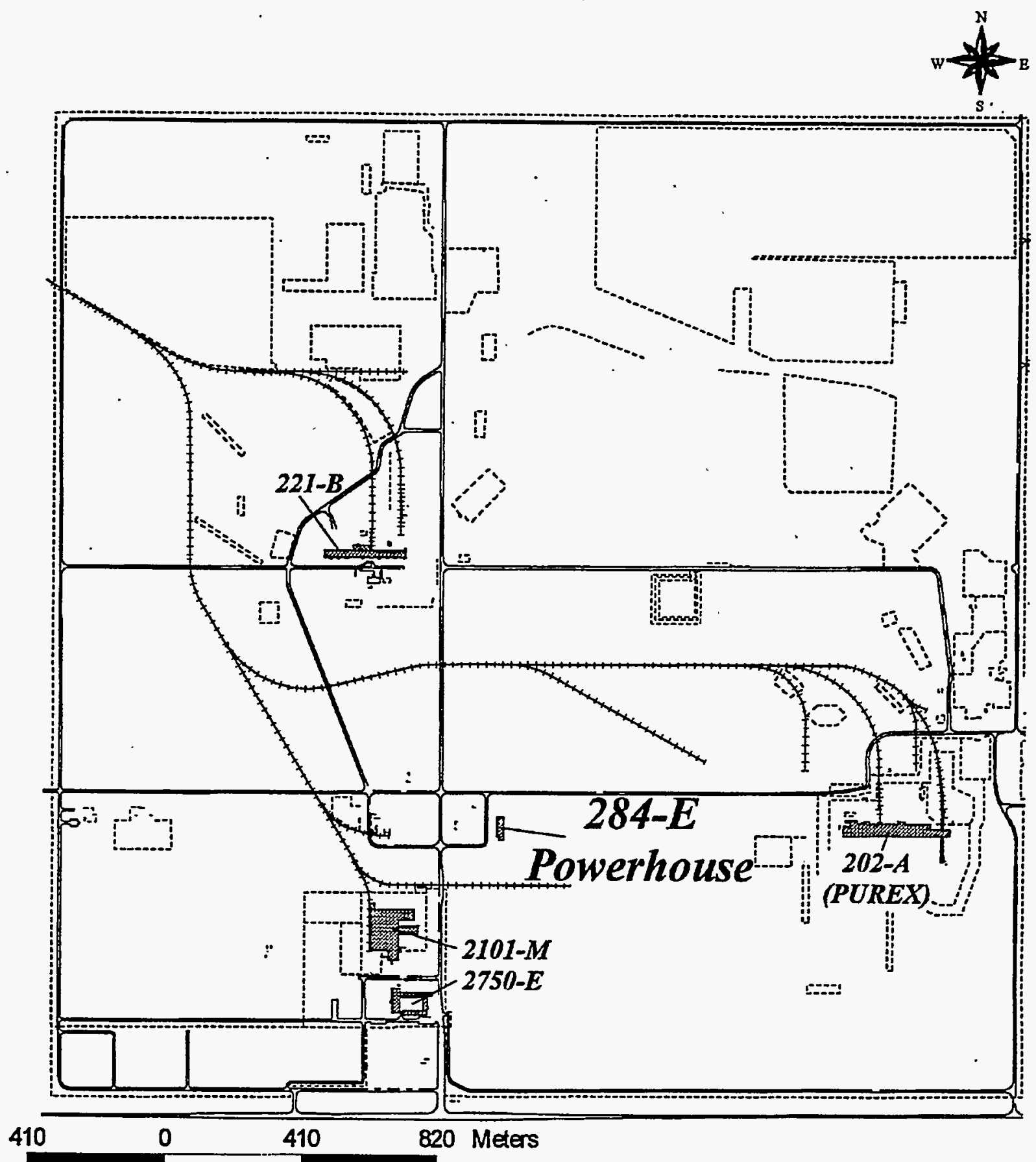

Figure 3. 200 East Area. 


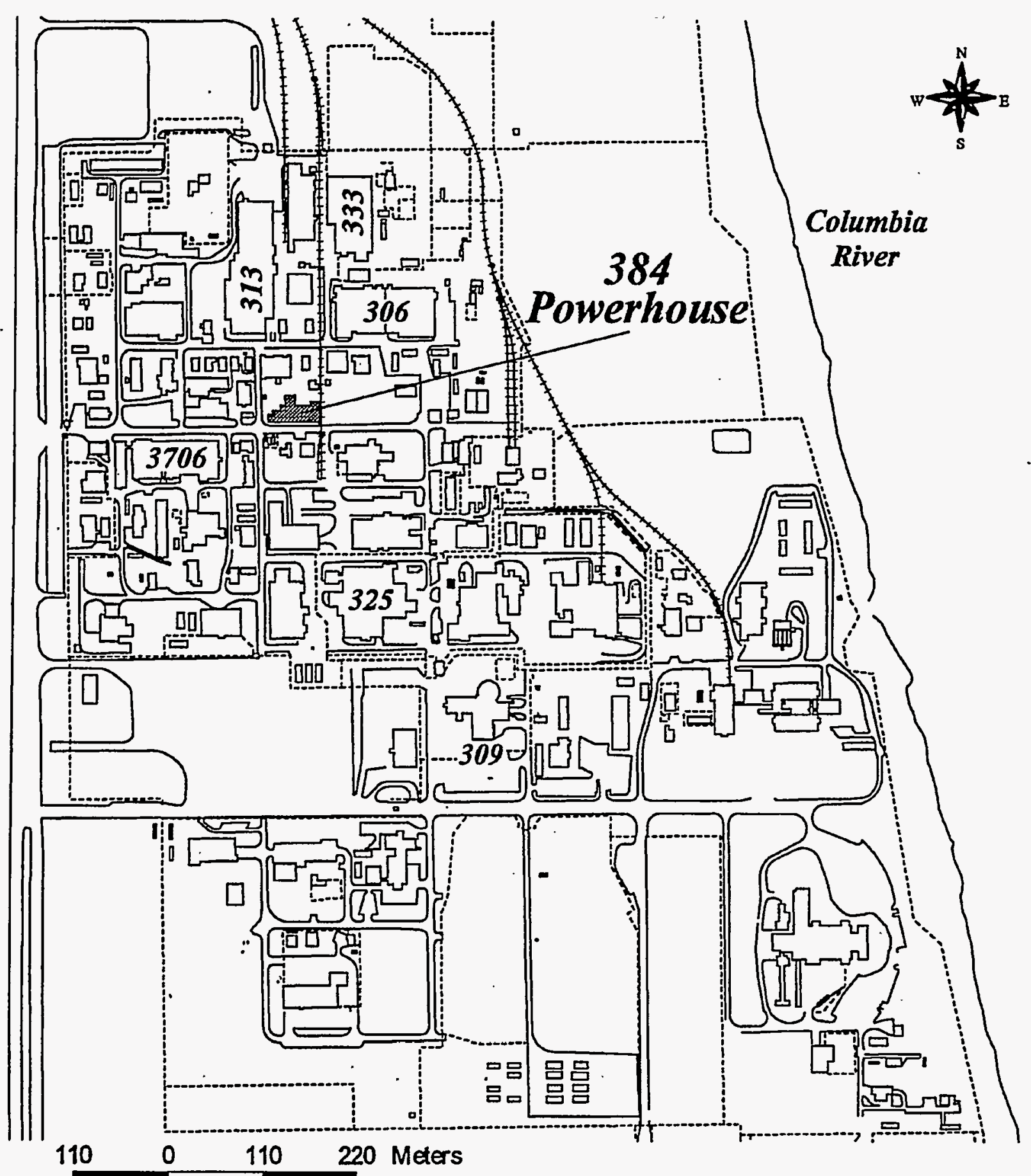

Figure 4. 300 Area. 


\subsection{ALTERNATIVES TO THE PROPOSED ACTION} sections.

Alternatives to the proposed action are discussed in the following

3.1 OTHER ALTERNATIVES. Other alternatives considered. CEQ regulations direct all agencies to identify reasonable alternatives that would achieve the purpose and need.

An alternative would keep the 200 West Area Steam Plant in surveillance and maintenance mode indefinitely. In addition. the 200 East Area and 300 Area Steam Plants would be put into surveiliance and maintenance mode indefinitely after deactivation activities. This alternative might occur if it is determined that bids from potential contractors for salvage and demolition of the steam plants are not cost effective versus the cost of surveillance and maintenance of the facilities.

Another alternative would be the reuse of the three steam plants for other activities. After evaluation, no foreseeable reuse has been identified.

3.2 NO ACTION ALTERNATIVE. CEQ and the DOE NEPA regulations require the DOE to analyze the "No Action al ternative," i.e., to examine what would happen if nothing were done. Hote that generally this is a cont inuation of the status quo.

The No Action alternative would keep the 200 West Area Steam Plant in surveillance and maintenance indefinitely. Following the shutdown of the 200 East Area and 300 Area Steam Plants, there would be no isolation activities and no decommissioning activities for those facilities. 


\subsection{AFFECTED ENVIRONMENT}

Existing environment to be affected by the proposed action and alternatives. Sumary information only should be provided, with more detailed information referenced.

The following sections provide a discussion of the existing environment to be affected by the proposed action and alternatives.

\subsection{GENERAL HANFORD SITE ENVIRONMENT}

The Hanford Site is 1,450 square kilometers (560 square mi les) located in southeastern Washington State, in a semiarid region with rolling topography. Two topographical features dominate the landscape: Rattlesnake Mountain is located on the southwest boundary with Gable Mountain located on the northern portion of the Hanford Site. The Columbia River flows through the northern part of the Hanford Site and forms part of the eastern boundary of the Hanford Site. Areas adjacent to the Hanford Site are primarily agricultural lands. The 200 West Area, 200 East Area, and the 300 Area of the Hanford Site have all been heavily used as industrial areas.

The Hanford Site has a mild climate with 15 to 18 centimeters ( 6 to 7 inches) of annual precipitation. with most of the precipitation taking place during the winter months. Temperature ranges of daily maximum temperatures vary from normal maxima of $2^{\circ} \mathrm{C}\left(36^{\circ} \mathrm{F}\right)$ in early January to $35^{\circ} \mathrm{C}\left(95^{\circ} \mathrm{F}\right)$ in late July. Infrequent periods of high winds of up to 128 kilometers ( 80 miles) per hour occur throughout the year. Tornadoes are extremely rare; no destructive tornadoes have occurred in the region surrounding the Hanford Site.

The Hanford Site and the surrounding area are in attainment of the National Ambient Air Quality Standards (NAAQS) designed to protect the public health and welfare. During 1994. the Hanford Site air emissions remained below all established limits set for regulated air pollutants (PNL 1995a). Atmospheric dispersion conditions of the area vary between summer and winter months. The summer months general7y have good air mixing characteristics. If the prevailing winds from the northwest are light. less favorable dispersion conditions might occur. Occasional periods of poor dispersion conditions occur during the winter months.

The vegetation on the Hanford Site is a shrub-steppe community of sagebrush and rabbitbrush with an understory consisting primarily of cheatgrass and Sandberg's bluegrass. The typical insects, sma17 birds, mammals, and reptiles common to the Hanford Site can be found in the 200 Area plateau (PNL 1995b). Relatively undisturbed areas of the mature shrub;-steppe . vegetation are high quality habitat for many plants and animals and have been designated as "priority habitat" by Washington State. However, al1 areas of the proposed action have been previously disturbed with human occupancy.

Most mammal species known to inhabit the Hanford Site are small. nocturnal creatures, primarily pocket mice and jackrabbits. Large mammals found on the Hanford Site are deer and elk, although the elk exist almost entirely on the Arid Lands Ecology Reserve. Coyotes and raptors are the primary predators. Several species of smail birds nest in the steppe 
vegetation. Semiannual peaks in avian variety and abundance occur during migration seasons:

The DOE-RL and its contractors dominate the local employment picture with almost one-quarter of the total nonagricultural jobs in Benton and Franklin counties. Ninety-three percent of Hanford Site personnel reside in the Benton and Franklin county areas. Therefore, work activities on the Hanford Site play an important role in the socioeconomics of the Tri-Cities (Richland, Pasco, and Kennewick) and other parts of Benton and Frank i in counties (PNL 1995b). Other surrounding counties could be impacted to a Tesser degree.

\subsection{SPECIFIC SITE ENVIRONMENT}

The 200 West Area Steam Plant in the 200 West Area and the 200 East Area Steam Plant and facilities in the 200 East Area are located on the 200 Area plateau, 8 kilometers ( 5 miles) and 16 kilometers (10 miles) from the Columbia River, respectively. The 300 . Area Steam Plant in the 300 Area is located about 1 kilometer (2/3 mile) from the Columbia River. The 200 Area plateau and the 300 Area are not located in the 100-year or 500-year floodplain of the Columbia River, nor are these located within a wetlands area (PNL 1995b). The 200 Area plateau and the 300 Area do not contain any prime farmland. state or national parks, forests, conservation areas, or other areas of recreational, scenic, or aesthetic concern. The City of Richland (population approximately $32.000)$. located in Benton County, adjoins the southernmost portion of the Hanford Site boundary and is the nearest population center.

\subsubsection{Soi.7s and Subsurface}

The soil in the 200 Areas and 300 Area is predominately a sand and gravel mixture. All areas of the proposed action are in previously disturbed soils. The geologic strata under the surface layer, in descending order, are Holocene eolian deposits. Hanford formation. Ringold Formation, and the Columbia River Basa7t Group. The eolian sands are fine- to coarse-grained, and relatively quartz- and feldspar-rich. Deposits of the Hanford formation underlie the eolian deposits. Hanford formation strata generally are dominated by deposits typical of the gravel-dominated facies consisting of uncemented granule to cobble gravels and minor coarse-grained sand. This is underlain by the top of the Ringold Formation. Basalt flows of the Columbia River Basalt Group and intercalated sediments of the Ellensburg Formation underlie the Ringold Formation. The region is categorized as one of low to moderate seismicity (PNL 1995b).

\subsubsection{Hydrology}

The water table in the 200 Areas is approximately 70 meters ( 230 feet) to 88 meters (290 feet) below the surface. The water table under the 300 Area Steam Plant is approximately 14 meters ( 45 feet) below the surface (PNL 1995b). 


\subsubsection{Air Resources}

The Hanford Site operates under a Prevention of Significant Deterioration (PSD) permit established by the U.S. Environmental Protection Agency (EPA) which is designed to protect existing ambient air quality. No distinctive increases in overal1 emissions are envisioned from the proposed action and would not trigger changes to the PSD permit.

\subsubsection{Plants and Animals}

Only a few species of plants and birds, and no mammals, are found in the immediate proximity of the steam plants due to the highly disturbed nature and human occupancy of the area. Cliff swallows are a migratory bird that were observed nesting on the coal ramp leading to the 200 West Area Steam Plant as indicated in Biological Survey \#96-200-047c (Appendix A). Under The Migratory Bird Treaty Act, it is illegal to take, capture, or ki11; as applicable, any migratory bird, or any part, nest, or egg of any such birds, included in the terms of the conventions. To avoid adverse impacts to this species. demolition of this building should be undertaken outside the nesting season that extends from April 1 to July 30.

\subsubsection{Endangered Species}

No plants or animals on the federal list of "Endangered and Threatened Wildlife and Plants" (50 Code of Federal Regulations [CFR] 17) are found in the immediate vicinity of the proposed action, as indicated in Biological Surveys \#96-200-047b\&c (Appendix A).

\subsubsection{Cultural Resources}

The RL has determined that the 284-West, 284-East, and the 384 Powerhouses are historic properties that are eligible for listing on the National Register of Historic Places (NPS 1995). These buildings were found to be contributing elements to the Manhattan Project and Cold War Era involvement and the Hanford Site Historic District (District). An agreement has been reached in the Programmatic Agreement Among the U. S. Department of Energy Richland Operations Office. the Advisory Council on Historic

Preservation, and the Washington State Historic Preservation Office for the Maintenance, Deactivation. A7teration, and Demolition of the Built Environment on the Hanford Site. Washington (PA) that sets forth the mechanism for mitigation of eligible historic Hanford buildings. The PA is the agreement mechanism that focuses the National Historic Preservation Act of 1966 Section 106 compliance on the Historic District, and directs DOE-RL to take actions specific to the Hanford Site. The specific issues surrounding the historical significance of the three powerhouses have been discussed between DOE-RL and the SHPO. See Appendix B for correspondence.

Two cultura\} resources reviews (HCRL \#96-200-047 and Addendum) have been completed by the Hanford Cultural Resources Laboratory for the 284-West 
Powerhouse. In addition. DOE-RL and the SHPO have concurred that the proposed action would have no adverse effect upon the District. which includes the 284-West Powerhouse (see correspondence in Appendix B). There were no known archeological, religious sites, or other sensitive cultural artifacts of significance found during the survey.

Two cultural resources reviews (HCRC \#96-200-035 and \#96-200-045) have been completed for the 284-East Powerhouse. In addition, a Historic Property Inventory Form (HPIF) was completed for the 284-East Powerhouse for mitigative purposes as specified in the PA.

A cultural resources review (HCRC \#96-300-025) was completed for the demolition of the 384 Powerhouse. The SHPO has concurred with RL that the 384 Powerhouse is a contributing structure to the District. The PA requires preparation of a HPIF for mitigation of the powerhouse demolition.

Cultural resources reviews for existing borrow pits \#4 and \#9 indicate that they have no identified archaeological resource (DOE 1995). Onsite personnel would be briefed on the requirements of cultural resources, and would be directed to watch for cultural artifacts during excavation. If cultural features or artifacts are encountered, work in the vicinity of the discovery would stop, and the appropriate cultural resource staff would be notified. Limited field analysis and documentation of any findings would be conducted before resuming excavation activities. The cultural resource staff would assess the significance of the find, and, if necessary, arrange for mitigation of the impacts to the find. 


\subsection{ENVIRONMENTAL IMPACTS}

potential environnental impacts from the proposed action and alternatives are discussed in the following sections. Impacts are addressed in proportion to their potential significance.

The following sections describe impacts from the proposed action.

\subsection{SALVAGE/DEMOLITION IMPACTS. Description of impacts from the salvage/demolition activities} of the proposed action.

Impacts from the salvage/demolition activities are described in the following sections.

\subsubsection{Soil or Subsurface Disturbance and the Consequences}

Al1 areas within the proposed action are previously disturbed areas. It is planned during the salvage/demolition phase to remove a17 foundation and concrete footings with a maximum depth of about 6 meters (20 feet), and the . steam distribution system poles with a maximum depth of about 2 meters ( 6 feet). The exact technique to dismantle each structure under the proposed action would be analyzed for its impact to the existing structures surrounding area before the required demolition plan is approved. If there is any hazardous or radioactive contamination found in the soils during excavation of the foundations of buildings or at the base of the steam distribution system poles, the contaminated soils would be covered with clean soil and left in place for remediation of the OU, or otherwise dealt with in a manner acceptable to the relevant regulatory agency. Al1 voids that would occur during this phase would be backfilled. Some fill material would come from existing Borrow Pits \#4 or \#9. The shallow coal storage pits would be utilized as a laydown yard during salvage and demolition activities, then have their bermed shoulders backfilled into the pit and leveled. The amount of soil disturbance would be minimal, because the proposed action would occur on highly disturbed grounds. In addition, a17 soil and subsurface activities would be temporary, therefore the anticipated impacts to the environment are not expected to be consequential.

\subsubsection{Liquid Discharges to the Groundwater or Surface Waters and the Consequences}

Other than sprinkling clean water for dust control, there would be no liquid discharges that may effect groundwater or surface waters.

\subsubsection{Gaseous, Particulate, or Thermal Discharges to the Air and the Consequences}

Small quantities of gaseous, particulate, or thermal discharge activities from such activities as trucks for transporting wastes or salvaged materials. welding/cutting, or backfilling may be generated for short periods of time during the salvage/demolition phase of the proposed action. Any particulate releases from dust would be watered down during salvage and excavation 
activities. However, once the steam plants are leveled, no further discharges would occur during this phase of the proposed action. The impacts of the proposed action are considered to be relatively minor.

\subsubsection{Radionuclide Releases or Direct Radiation Exposure and the Consequences}

There would be no radionuclide releases or direct radiation exposure.

\subsubsection{Nonhazardous Solid Waste Generated and the Consequences}

It is expected that only nonhazardous solid waste would be generated during the salvage/demolition phase of the proposed action. Once the steam plants are leveled, and inert and demolition waste removed, no further waste generation would occur. The inert and demolition waste generated from the steam plants would be disposed of into existing borrow pits \#4 or \#9. The. addition of inert and demolition waste into an onsite landfill would be smal1 compared to the overal1 capacity of the existing borrow pits on the Hanford Site. In addition, existing facilities would have adequate capacity to accept al1 other waste volumes from the proposed action. A11 nonhazardous waste would be disposed in accordance with applicable requirements. Therefore, these impacts to the environment are expected to be sma11.

\subsubsection{Hazardous or Dangerous Waste Generated and the Consequences}

A waste management plan would be submitted by the selected contractor at least 5 days before starting work on the proposed action. The contractor would describe in the plan al1 potential hazardous waste (e.g., solvents and/or cleaning agents). exclusive of the materials and equipment identified as part of the buildings and facilities of the proposed action, that are expected to be generated during the performance of the contract. The plan would include quantity of waste and how the waste would be managed. These materials would be managed and disposed of in accordance with applicable federal and state regulations. Waste generation resulting from the proposed action is expected to be minimal compared to annual Hanford Site waste generation. Therefore, these impacts to the environment are not expected to be consequential.

\subsubsection{Hazardous Substances Present and the Consequences}

All asbestos handling activities would follow approved procedures and requirements as directed in Title 40 . Code of Federal Regulations (CFR) Parts 61 and 763, and under Washington Administrative Code (WAC) 296. Chapters 62 and 65 . The local Benton County Clean Air Authority would be notified before any asbestos handling activities as required. An example of the controls would be to wet the asbestos material. place asbestos material in plastic bags, tie bags shut to prevent release of airborne fibers, and place bagged asbestos material into a second plastic bag, or other approved closable 
and impermeable container, and close airtight. All approved packaged asbestos would be disposed of offsite at a private, permitted disposal facility.

Sma17 amounts of lead and PCBs have been identified in the 200 West Area Steam Plant. A71 lead handling activities would follow approved procedures and requirements as directed in 29 CFR 1910 and 1926. The only PCBs that may be expected to be present in the powerhouses would be contained in the light ballasts. If PCBs are found in the light ballasts, they would be dealt with in a manner acceptable to the relevant regulatory agency.

Any materials that might be discovered later in the buildings would be managed in accordance with applicable federal and state regulations. Potential impacts to the environment would be minimized through strict compliance with the applicable regulatory requirements. Due to the smal1 quantities of these materials, the effects of the proposed action are not expected to be consequential.

\subsubsection{Any Disturbance to Previously Undeveloped Areas and the Consequences}

There would be no disturbance to previously undeveloped areas.

\subsubsection{Consumption or Commitment of Nonrenewable Resources}

Consumption of nonrenewable resources (e.g. . petroleum products, diesel fuel, etc.) would occur for short periods during the salvage/demolition phase of the proposed action. The amount of consumption is minimal; therefore. these impacts to the environment are not expected to be consequential.

\subsubsection{Effects on Cultural Resources}

Issues surrounding the cultural resources of the three powerhouses are discussed in Section 4.2.6 and are included in Appendix B.

DOE-RL and the SHPO have concurred that the proposed action would have no adverse effect on the Hanford Site Historic District, of which the 284-West Powerhouse is part of this district. The SHPO has concurred with RL that the 384 Powerhouse is a contributing structure to the Hanford Site Historic

District. Since the PA between the DOE-RL. SHPO, and the Advisory Council on Historic Preservation allows mitigation of these buildings through preparation of an HPIF, it is expected that there would be no adverse effects on the. cultural resources of the proposed action.

\subsubsection{Effects on Federaliy or State Listed, Proposed or Candidate, Threatened or Endangered Species}

No Federa7ly or State listed, proposed or candidate, threatened, endangered species are expected to be effected by the proposed action. 


\subsubsection{Effects on any Floodplain or Wetland}

The proposed action is outside any floodplains and wetlands.

\subsubsection{Effects on any. Wild and Scenic River, State or Federal Wildlife Refuge, or Specially Designated Area}

The proposed action is outside any Wild and Scenic River corridor, state or federal wildlife refuge, or specially designated area.

\subsubsection{Reasonably Foreseeable Accidents Considered and the Effects}

The only reasonably foreseeable accidents under the proposed action would be typical construction hazards associated with salvage and demolition activities, including possible blasting, and with the subsequent backfilling activities. Areas would be roped off and cleared of personnel prior to any blasting. The areas affected by blasting would be restricted to the building site. Personnel handling recycle, and salvage/demolition activities would follow approved safety procedures for the salvage and demolition of the facilities within the proposed action, in addition to loading inert and demolition waste into dump trucks and transporting the material to an inert/demolition waste landfill on the Hanford Site, soil backfilling, and water spraying for dust control. Typical construction hazards occur, however the risk of severe accidents is sma?

\subsection{SOCIOECONOMIC IMPACTS. Description of socioeconomic impacts that would result from the proposed action.}

Only small numbers of workers would be involved in the salvage/demolition actions at any one time. No substantial change is expected in the number of Hanford Site personnel as a result of the proposed action. No discernible impact to employment levels within Benton and Franklin counties is expected.

5.3 ENVIRONMENTAL JUSTICE IMPACTS. Description of envirommental justice impacts that would result from the proposed action.

Executive Order 12898. Federal Actions to Address Environmental Justice in Minority Populations and Low-Income Populations, requires that federal agencies identify and address, as appropriate, disproportionately high and adverse human health or socioeconomic effects of their programs and activities on minority and low-income populations. Minority (especially Hispanic) populations and low income populations are present near the Hanford Site (PNL 1995a). The DOE is in the process of developing official guidance on the implementation of the Executive Order. The analysis of the impacts in this EA indicates that there would be minimal impacts to both the offsite. population and potential workforce by implementing the proposed action, because the entire proposed action would occur on the Hanford Site and the offsite environmental impacts from the proposed action analyzed in this EA are expected to be minima?. Therefore, it is not expected that there would be any 
disproportionate impacts to any minority or low-income portion of the community.

5.4 CUMULATIVE IMPACTS. Description of the cumulative impacts that would result from the proposed action.

Waste generation resulting from the proposed action is not expected to be substantial compared to annual Hanford Site waste generation. For example. small quantities of low-concentration hazardous waste (e.g.. solvents or cleaning agents) could be generated as a result of performing the proposed activities. These materials would be managed and recycled or disposed of in accordance with applicable federal and state regulations. Disposal of wastes as a result of the proposed action would not substantialiy effect any associated disposal sites. The proposed action would return all associated areas to level ground for potential reuse or a return for natural habitat use. Because the proposed action would involve personnel relocated from various areas within the Hanford Site, no substantial change is expected in the overall workforce of the Hanford Site. The potential impacts from the proposed action are not expected to contribute substantially to the cumulative impacts of operations on the Hanford Site.

\subsection{IMPACTS FROM ALTERNATIVES}

Alternatives and the No Action Alternative are discussed in the following sections.

5.5.1 Implementation of A7ternatives. Qualitative discussion on impacts that would result from implementation of alternatives.

Under the indefinite surveillance and maintenance alternative, the immediate impacts to the environment would not change. However, small amounts of hazardous materials such as lead paint or asbestos may be released to the environment over time. The longer any of the powerhouse facilities stay in surveillance and maintenance following deactivation, the more costly they are to maintain and clean up. In addition. the building structures may deteriorate to unsafe conditions.

Under the reuse alternative, since there are no foreseeable reuses of the facilities, there would be no immediate impacts on the environment. However. if there were reuses identified, refurbishment would remove any hazardous materials.

5.5.2 Implementation of the No Action Alternative. Qualitative discussion on impacts that would result from implementation of the no action al ternative.

Under this alternative, the immediate impacts to the environment would not change. However, as the buildings age, they would be more costly to . maintain. 


\subsection{PERMITS AND REGULATORY REQUIREMENTS}

Regulatory requirements affecting the proposed action and necessary permits.

It is the policy of DOE-RL to carry out its operations in compliance with al1 applicable federa7, state, and local laws and regulations. Presidential Exeçutive Orders, and DOE Orders. Asbestos handling activities would require a permit to follow approved procedures and requirements as directed in 40 CFR Parts 61 and 763, and under Washington Administrative Code (WAC) 296. Chapters 62 and 65 . The local Benton County Clean Air Authority would be notified before any asbestos handling activities' as. required. The proposed action would follow pollution prevention requirements under Executive Order 12856: Federa7 Comp7iance with Right-To-Know Laws and Pollution Prevention Requirements. Environmental regulatory authority over the Hanford Site is vested in federal agencies and in Washington State agencies. The proposed actions would comply with all of these and other environmental requirements in a manner acceptable to the relevant regulatory agency while handling, recycling, salvaging, and disposing of a 71 materials, including asbestos, lead, mercury. PCBs, and other sma11 amounts of hazardous substances and materials, nonhazardous materials, as well as disposal of inert and demolition wastes, as applicable. 


\subsection{ORGANIZATIONS CONSULTED}

Tribes, government agencies, and other interested parties consulted during the preparation of this document.

The DOE has consulted the SHPO regarding the three powerhouses. The powerhouses are eligible for listing on the National Register of Historic Places (NPS 1995). An agreement has been reached between DOE-RL, the SHPO. and the Advisory Council on Historic Preservation in the PA that sets forth the mechanism for mitigation of eligible historic Hanford buildings.

Prior to approval of this EA, a draft version was sent to the Nez Perce Tribe, the Confederated Tribes of the Umatilla Indian Reservation, the Wanapum, the Yakama Indian Nation. Washington State, U.S. Fish and Wildlife Service, and Physicians for Social Responsibility for a 15 day review period. However, no comments were received. 


\subsection{REFERENCES}

10 CFR 1021. DOE "National Environmental Policy Act Implementing Procedures".

29 CFR 1910. "Occupational and Safety Health Administration".

29 CFR 1926. "Safety and Health Regulations for Construction".

40 CFR 61. "National Emission Standards for Hazardous Air Pollutants".

40 CFR 763, "Asbestos".

40 CFR 1500-1508. Council on Environmental Qua7ity "Regulations for Implementing the Procedural Provisions of the National Environmental Policy Act".

50 CFR 17. "Endangered and Threatened Wild7ife and Plants".

Comprehensive Environmental Response. Compensation. and Liability Act of 1980. as amended. 42 U.S.C. 9601 et seq.

DOE, 1995. Environmenta7 Assessment: Inert/Demolition Waste Landfil1 (Pit 9), Hanford Site, Richland. Washington, DOE/EA-0983, U.S. Department of Energy, Washington, D.C.

DOE-RL, 1996. Programmatic Agreement Among the U. S. Department of Energy Richland Operations Office, the Advisory Council on Historic Preservation, and the Washington State Historic Preservation Office for the Maintenance. Deactivation. Alteration, and Demolition of the Built Environment on the Hanford Site, Washington. U.S. Department of Energy. Richland Operations Office, Richland, Washington.

Migratory Bird Treaty Act, 16 U.S.C. 1431 - 1543, et seq.

National Environmenta7 Po7icy Act of 1969, 42 U.S.C. 4321 et seq.

National Historic Preservation Act of 1966, 16 U.S.C. 470 et seq.

NPS, 1995. The National Register of Historical Places, National Park Service. U.S. Department of Interior, Washington, D.C.

PNL, 1995a, Hanford Site Environmental Report for Calendar Year 1994. PNL-10574. Pacific Northwest Laboratory, Richland, Washington.

PNL, 1995b, Hanford Site National Environmental Policy Act (NEPA) Characterization. PNL-6415. Rev. 7. Pacific Northwest Laboratory. Richland. Washington.

WAC 296-62, "Occupational Health Standards - Safety Standards for Carcinogens". 
WAC 296-65. "Asbestos Removal and Encapsulation". 

APPENDIX A

BIOLOGICAL REVIEWS 

Pacific Northwest National Laboralory

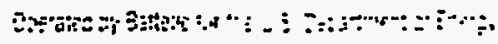

May 14, 1996

$376-5345$

Mr. J. Diebel

ICF Kaiser Hanford Company

P. 0. Box 888, MSIN S2-66

Richland, WA 99352

Dear Mr. Diebel:

SECOND SUPPLEMENTAL BIOLOGICAL REVIEW OF THE COAL PIT, ASH PIT, AND ASH DISPOSAL BASIN IN SUPPORT OF THE 284-W AND 2710-W DE-ACTIVATIONISHUTDOWN, 200

West Area, \#96-200-047b

\section{Project Description:}

- Excavations within the coal pit, ash pit, and ash disposal basin in support of the demolition of the 284$W$ Building and 2710-W Building.

\section{Survey Objectives:}

- To determine the occurrence in the project area of piant and animal species protected under the Endangered Species Act (ESA), candidates for such protection, and species listed as threatened, endangered, candidate, sensitive, or monitor by the state of Washinglon. and species protected under the Migratory Bird Treaty Act.

- To evaluate the potential impacts of disturbance on priority habitats and protected plant and animal species identified in the survey.

\section{Survey Methods:}

- Pedestrian and ocular reconnaissance of the coal pit, ash pit, and ash disposal basin was conducted by G. Fortner, R. Zufelt, R. Burrows, and G. Laugheed on May 13, 1996. The Braun-Blanquet coverabundance scale (Bonham 1989) was used to determine percent cover of dominant vegetation.

- Priority habitats and species of concern are documented as such in the following: Washington Department of Fish and Wildlife $(1993,1994)$, U.S. Fish and Widlife Service $(1985,1994 a$ \& b) and Washington State Department of Natural Resources (1994).

\section{Survoy Results:}

- The coal pit, ash pit, and ash disposal basin are disturbed. Vegetation is sparse and consists primarily of Russian thistle (Salsola kall) and cheatgrass (Bromus tectorum), both alien annual weeds.

- No migratory birds were observed nesting in the vicinity of the coal pit, ash pit, or ash disposal basin. 
Mr. J. Diebel

96-200-047b

Page 2 of 3

\section{Considerations and Recommendations:}

- No plant and animal species protected under the ESA, candidates for such protection, or species listed by the Washington state government were observed in the vicinity of the coal pit, ash pit, or ash disposal basin:

- No adverse impacts to species or habitats of concern are expected to occur from the proposed action.

- This biological review is effective until April 1, 1997. Should work on this project commence after this date, a new ecological review will be required.

Sincerely.

9.m. Becker for C.A. Brandt

CA Brandt, Ph.D.

Project Manager

Ecological Compliance Assessment

CAB:jmb 
Mr. J. Diebel

96-200-047b

Page 3 of 3

\section{REFERENCES}

Bonham, Cliarles D. 1989. Megsurements for Terrestrial Vegetation, published by John Wiley \& Sons, Inc. pp. 127-128.

U. S. Fish and Wildife Service. 1985. Revised List of Migratory Birds; Final Rule. 50 FA 13708 (April 5 , 1985).

U. S. Department of Interior, U. S. Fish and Wildlife Service. 1992a. Endangered and Threatened Wildlife and Plants. 50 CFR 17.11 and 17.12. (August 29, 1992).

U, S. Fish and Wildife Service. 1994b. Endangered and Threatened Wildlife and Plants, Animal Candidate Review for Listing as Endangered or Threatened Species, Proposed Rule, 50 CFR 17. (November 15. 1994).

Washington Department of Fish and Wildife. 1993. Priority Habitats and Species. pp. 22.

Washington Department of Fish and Wildlife. 1994. Species of Special Concern in Washington. (April 1994).

Washington Department of Natural Resources. 1994. Endangered, Threatehed \& Sensittve Vascular Plants of Washington. (January 1994). 


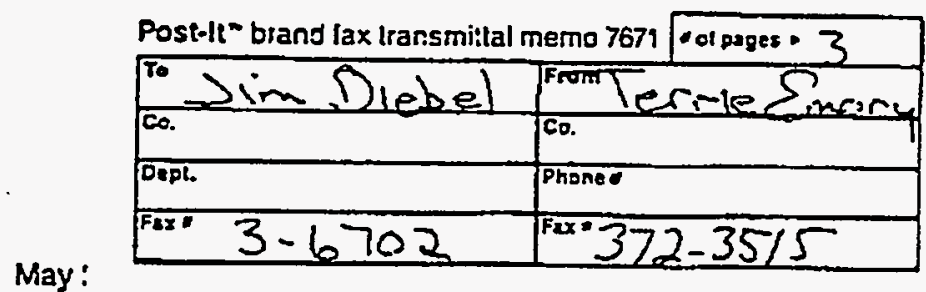

May:

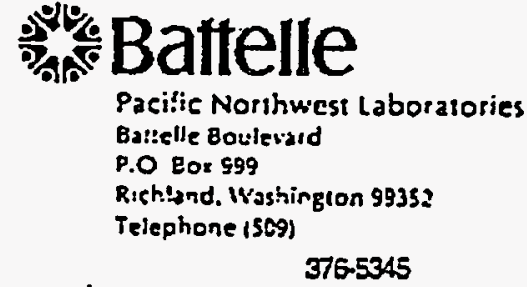

MS. J. L. Day

ICF Kaiser Haniord Company

P. 0. Box 888, MSIN S2-66

Richland, WA 99352

Dear Mr. Dey.

BIOLOGICAL REVIEW OF THE 284-W DE-ACTIVATION/SHUTDOWN, 200 West ATEa, $\$ 96-200 \cdot 047 \mathrm{C}$

Project Description:

- Demolition of the $284 \cdot W$ Building.

Survey Objeelives:

- To determine the cccurience in the project area of plant and enimal species prolected under the Endangered Species ACt (ESA), candidales for such protection, and spocies listed es threatened, endengered, candidate, sensitive, or monitor by the stale of Weshingion, and species protected under the Migratory Bird Treaiy Act.

- To evaluate the poteritial impacts of disturbence on priority habitais and protected plant and animal species identified in the survey.

Survey Methods:

- Pedestrian and ocular reconnaissence of the proposed site was conducled by R. Zutelt, G.Foriner, R. Burrows and G. Loughheed on May 23, 1996. The Braun-Blenquet cover-abundance scale (Bonham 1989) was used to determine percent cover of dominanl vegetation. Avian surveys of buildings in the 200 West Area were conducted by by R. Zuleit, G.Forner, R. Burrows and G. Loughheed on May 13, 1996.

- Priority habilats and species of concern are documented as such in the follewing: Washington Depantment of Fish and Wildife $(1993,1994)$, U. S. Fish and Wildlife Senvice $(1985,1994 a$ \& b) and Washington State Department of Natural Resources (1994).

Survey Results:

- The vicinity of the buiiding is oisturbed. Vegetation is sparse and consists primarily of big fabbitbrush (Chrysothamnus náuseosus), cheatgrass (Bromus tectorum). Jim Hill's tumble mustard (Sisymbrium altissimum), and Sandcerg's bluegrass (Poa sanjibergin.

- House sparrows (Passer domesticus), European Slatings (Sivinus vulgeris), and Rocik Doves (Columbia livia) were observed perching on the 284-W Builcir.s. Cliff swallows were observed nesting on the coal ramp leading to the 284-W Builcing. 
Mr. J.L. Day

96-200-047c

Page 2 of 3

\section{Considerations and Recommendalions:}

- The Migratory Birs Treaty Act makes it illegal to take, captu:e, of kill, as applicable, any migratory bird, or any part, nest, or egg of any such birds, included in the terms of the conventions.

- Cliff swallows are a migratory bird and are protected under the Migralory Bird Treaty Act. In order to avoid adverse impacts to this species, demolition of this building should be undertaken outside the nesting season that extends trom April 1 10 July 30.

- This biological review is effective until April 1. 1997. Should work on this project commence after this date, a new ecological review will be required.

- No other plant and animal species protected under the ESA, candidates for such protection, or specles listed by the Washington slate government were observed in the vieinity of the $284-W$ Building.

- No adverse ir.pacts to species or habitats of concern are expected to occur fircm the proposed demalitions.

\section{Sincerely,}

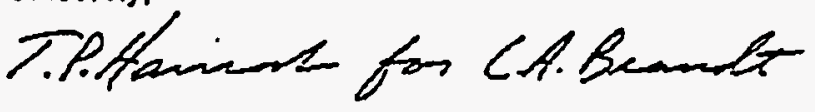

CA Brandl, Ph.D.

Project Managet

Ecological Compliance Assessment

CAB:jimb 
Mr. J.L. Day

96-200-047c

Page 3 of 3

\section{REFERENCES}

Bonham, Charles D. 1989. Measyremeris for Terrestrial Vegetation, published by John Wiley \& Sons, Inc. pp. 127-128.

U. S. Fish and Wildife Service. 1985. Revised List of Migratory Birds; Final Rule. 50 FR 13708 (April 5, 1985).

U. S. Depariment of Interior, U. S. Fish and Wildlife Sevice. 1992a. Endangered and Threatened Wildife and Plants. 50 CFR 17.11 and 17.12. (August 29. 1992).

U. S. Fish and Wildlife Service. 1994b. Endangered and Threalened Wildlife and Plants, Animal Candidate Review for Listing as Endangered or Threelened-Species, Proposed Rule, 50 CFR 17. (November 15, 1994).

Washington Department of Fish and Wildilie. 1993. Priority Hzbitats end Species. pp. 22.

Washington Depanment of Fish and Willife. 1994. Species of Speciel Concern in Washingten. (April 1994).

Washington Department cf Natural Resources. 1994. Endangered, Threatened \& Sensitive Vascular Plants of Washington. (January 1994). 


\section{APPENDIX B}

\section{CULTURAL RESOURCES REVIEWS AND CORRESPONDENCE}




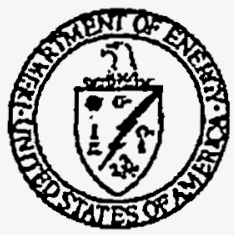

\section{- Department of Energy \\ Richland Operations Office \\ P.O. Box 550}

Richland, Washington 99352

\section{MAR 211996}

96-AIM-041

Ms. Mary M. Thompson

State Historic Preservation Officer

Office of Archaeology and Historic Preservation

Hashington Department of Community,

Trade and Economic Development

P.0. Box 48343

Olympia, Washington 98504-8343

Dear Ms. Thompson:

DEMOLITION OF THE 284-W POHER HOUSE BUILDING, HANFORD SITE

The U.S. Department of Energy, Richland Operations Office (RL) wishes to demoitsh the 284-H Power House Building, Hanford Site, because the facility is too expensive to mairitain and survey. If this building can be removed, funds that currently are used to maintain the structure can be re-directed into other site clean-up activities in support of the Hanford mission.

In 1995, your office was provided with a Historic Property Inventory Form (HPIF) (95-TEP-264) for the 284-W Power House, stating RL's belief that this building is not eligible for the National Register. On August 31, 1995, your office informed RL that the 284-W Building is a Register-eligible structure that played a key support role in the historic Hanford site mission (Log \#081095-119-DOE). Since that time, we have mutually discussed a site-wide mitigation plan that would encompass the roles of support buildings in Hanford's history.

The Historic Buildings Task Group has discussed the role of support buildings and how they contribute to the proposed Hanford Site District. The roles are minor and not significant. Based on the minor role that the 284-W Power House Building contributed to the Hanford site, it is RL's opinion that the documentation supplied in the HPIF is sufficient to support a "no adverse effect finding" at this time for the demolition of the building. 
Mary M. Thompson

96-AIH-04I

Therefore, in accordance with 36 CFR 800.5 (d), I am informing you of RL's need to demolish the 284-W structure and have provided documentation supporting this finding and solicit any comments you may have. If you have any further questions, please contact Mr. Mike Elsen, Site Infrastructure Division, at (509) 376-8021.

SID:MJE

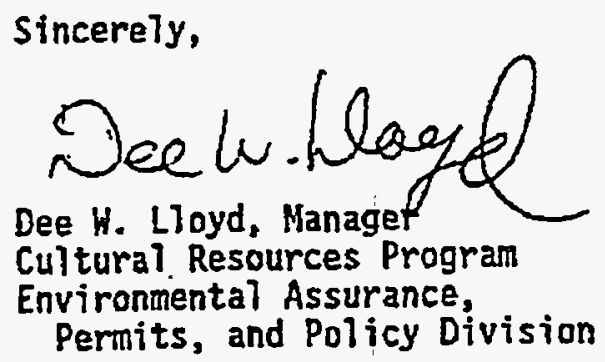

cc: J. Van Pelt, CTUIR

P. R. Nickens, PNNL

H. S. Gerber, WHC

G. T. Kirk, PNNL

R. C. Funderburg, ICF KH

D. L. Nícandri, WSHS

R. Buck, Hanapum

R. Jim, YIN

L. Malatare, YIN

R. S. Fintknife, YIN

J. H. Reuben, NPT 


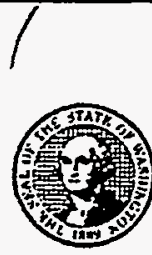

STATE OF WASHINGTON

\section{DEPARTMENT OF COMMUNITY, TRADE AND ECONOMIC DEVELOPMENT OFFICE OF ARCHAEOLOGY AND HISTORIC PREESERVATION 111 21st Avenue S.W. - P.O. Box 48343 • Olympia, Washington 985048343 • (360) 753-4011 March 28, 1996}

Mr. Dee W. Lloyd, Manager

Culltural Resources Program

Department of Energy

Richland Operations Office

Post Office Box 550, A5-15

Richland, Washington 99352

Log: 081095-119-DOE

Re: Demolition of the 284-W Power House

Dear 154. Lloyd: Dew.

Building, Hanford Site

The Washington State Office of Archaeology and Historic Preservation (OAHP) is in receipt of your letter regarding the above referenced action. From your letter, I understand that the Department of Energy (DOE) proposes to demolish the 284-W Power House Building at the Hanford Site.

In response, I want to thank you for information on the history of our consultation regarding this property. In view of the fact that OAHP and DOE has recently met, reviewed, and tentatively approved the Hanford Site Historic District Mitigation Plan, I concur with your determination that the proposed action will have no adverse effect upon the National Register eligibility of the Hanford Site Historic District. I have reviewed the mitigation plan matrices to confirm that no mitigation is recommended for $284-W$. I also note that $284-\mathrm{E}$ is recommended for mitigation through completion of a Historic Property Inventory Form (HPIF). As a result of this. concurrence, further contact with OAHP on this action is not necessary. However, should new information become avallable which could alter this opinion, please contact OAHP for further consultation.

Thank you for the opportunity to review and comment. Should you have any questions, please feel free to contact me at (360) 753-9116.

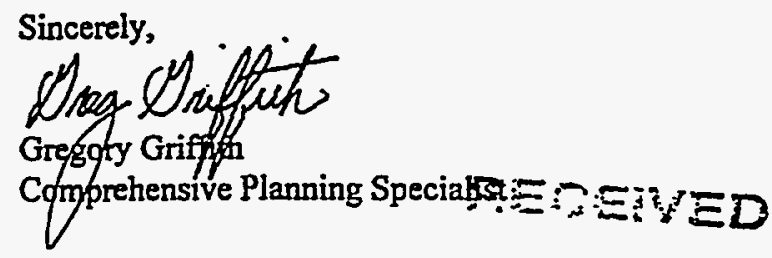

GAG:tit

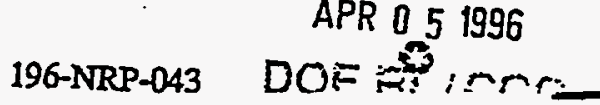




\section{Pacific Northwest National Laboratory}

Cperstec by 3as:s's lor the U.S Depatimert ol Ene:zi

April 8, 1996

No Known Archaeological Historic Properties

Mr. J.L. Day

ICF Kaiser Hanford

P.O. Box 888/S2-66

Richland, WA 99352

Dear Mr. Day:

CULTURAL RESOLRCES REVIEW OF THE 284W/2710W DEMOLITION. HCRC \#96-200-047.

In response to your request received April 1, 1996, staff of the Hanford Cultural Fesources Laboratory (HCRL) conducted a cultural resources review of the subject project, located in the 200 West Area of the Hanford Site. According to the information that you supplied, the $284 \mathrm{~W}$ and $2710 \mathrm{~W}$ facilities will be demolished. Excavation to a depth of 5 to 6 feet will be necessary for the removal of the $284 \mathrm{~W}$. foundation and deeper for the removal of the uncerground portion of the $2710 \mathrm{~W}$ facility.

Our literature and records review shows that the project area is located within the industrial part of the 200 West Area. The ground around the buildings has been extensively disturbed by previous Hantord Site construction activities, including the construction of the buildings. It is unlikely that any intact archaeological materials will be affected by the proposed project. Survey and monitoring of the project by an archaeologist are not necessary.

It is the finding of the HCRL staff that there are no known cultural resources or archaeological historic properties within the proposed project area. The workers, however, must be directed to watch for cultural materials (e.g., bones, artifacts) during alt work activities involving excavation. If any are encountered, work in the vicinity of the discovery must stop until an HCRL

archaeologist has been notified, assessed the significance of the find, and, if necessary, arranged for mitigation of the impacts to the find. The HCRL must be notified if any changes to project focation or scope are anticipated. This project is a Class VI case, defined as a project which involves demolition or remodeling of existing structures. It is my understanding that $M$. S. Gerber, Westinghouse Hanford Company, is evaluating the effect the demolition will have on potential contributing properties to the Hanford Site Historic District.

Copies of this letter have been sent to Dee Lloyd, DOE, Richland Operations Office, as official documentation. If you have any questions, please call me at 376-8107. Please use the HCRC\# above for any future correspondence concerning this project.

Very truly yours.

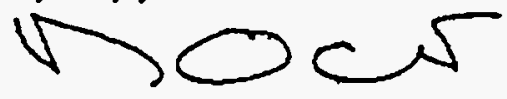

N. A. Cadoret

Concurrence:

Technical Specialist

Cullural Resources Project

Phal $R$.

P. R. Nickens, Project Manager Cultural Resouices Project

cc: D. Lloyd, RL (2)

J. A. Diebel

Filen.B 


\section{Pacific Northwest National Laboratory

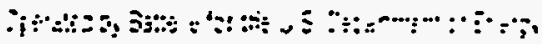

April 29, 1996

No Known Archaeological Historic Properties

Mr. J. A. Diebel

ICF Kaiser Hanford

P.O. BOX 888/G3-10

Pichland, WA 99352

Dear Mr. Dlebel:

CULTURAL RESOURCES REVIEW OF THE 284W/2710W DEMOLITION. ADDENDUM HCRC \#96-200-047.

REFERENCE: HCRC \#96-200-047 review letter dated April 8, 1996, from N. A. Cadoret, HCRL, to J. L. Day, ICFK.

Staff of the Hanford Cultural Resources Laboratory (HCRL) recently conducted a cultural resources review of the subject project. located in the 200 West Area of the Hanford Site (see reference above). You have since provided us additional information and project scope. According to this information, fand to within 20 feet of the $284 \mathrm{~W} / 2710 \mathrm{~W}$ complex may also be disturbed as a result of the demolition. The coal pile, ash pit, and ash disposal basin, to the south and southeast of the 284W/2710W. complex may also be disturbed/mined by the demolition project.

The project area is located within the industrial part of the 200 West Area. The ground around the buildings, coal pile, ash pit, and ash disposal basin has been extensively disturbod by previous Hanford Site activities. The coal pile, ash pit, and ash disposal basin are not themselves considered cultural resources. It is unlikely that any intact archaeological materials will be affected by the proposed project. Survey and monitoring of the project by an archaeologist are not necessary.

It is the finding of the HCRL statf that there are no known cultural resources or archaeological historic properties within the proposed project area. The workers, however, must be directed to watch for cultural materials (e.g., bones, artifacts) during all work activities involving excavation. If any are encountered, work in the vicinity of the discovery must stop until an HCRL archaeologist has been notified, assessed the significance of the find, and, if necessary, arranged for mitigation of the impacts to the find. The HCRL must be notified if any changes to project location or scope are anticipated. This project is a Class VI case, defined as a project which involves demolition or remodeling of existing structures.

Copies of this letter have been sent to Dee Lloyd, DOE, Richland Operations Office, as official documentation. If you have any questions, please call me at 376-8107. Please use the HCRC\# above for any future correspondence concerning this project.

Very truly yours,

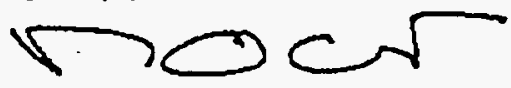

N. A. Cadoret

Concurrence:

Technical Specialist

P. R. Nickens, Project Manager

Cultural Resources Project Cultural Resources Project

cc: D. Lloyd, RL (2)

FilenB 
J. E. Rasmussen, Director

Environmental Assurance, Permits, and Policy Division

U.S. Department of Energy

Richland Operations Office

Richland, Washington 99352

Dear Mr. Rasmussen:

DEACTIVATION OF BUILDING 284-E AND MODIFICATION OF 282-E, HANFORD SITE (HCRC \$96-200-035 AND \#96-200-045)

A cultural resources review was conducted by qualified staff of Westinghouse Hanford Company at the request of ICF Kaiser Hanford Company on the deactivation of the 284-E Building, and the replacement of pumps in the 2B2-E Building, Hanford Stte. Both the 284-E and 282-E Buildings were found to be contributing structures to a potential Hanford site Historic District. Due to the need to deactivate the 284-E Building and to replace pumps in the 282-E Building as part. of cost-saving and efficiency measures in the Hanford Site cleanup mission, Historic Property Inventory Forms were completed on these buildings. Copies of these forms are enclosed.

The deactivation of the 284-E Building will consist of isolating equipment from power sources, shutting off and diverting water supplies, cleaning out residual debris, and housekeeping measures. Essential equipment such as the bojlers will be left in place awaiting future decontamination and decomissioning work. In the 282-E Butlding, the current pumps will be replaced with new pumps. However, the 282-E reservoir will continue to function. Likewise, parts of the steam distribution system in the 200-E Area will continue to function, but steam will be supplied by portable generating units located near the points of need. Therefore, it is the conclusion of the Westinghouse Hanford cultural resources office that the deactivation of the 284-E Building and the replacement of pumps in the 282-E Building will not have an adverse effect on them under provisions of the National Historic Preservation Act and its implementing regulations.

We, therefore, request that you forward this information and the enclosed forms to the Hashington State Historic Preservation Office to obtain concurrence on plans to deactivate the 284-E structure and to replace pumps in the 282-E structure with no further historical documentation effort at 
Page 2

Apri7 8, 1996

this time. These buildings will receive further future mitigation according to the proposed Site-wide Progranmatic Agreement for the Built Environment. If any archaeological or additional historical resources are discovered during demolition activities, work will be halted and your office informed immediately.

Very truly yours,

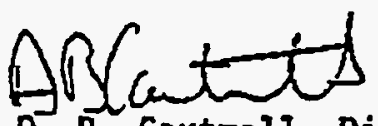

D. B. Cartmel1, Director

Transition Programs

Transition Projects

$d c$

Enclosures

Concurrence:

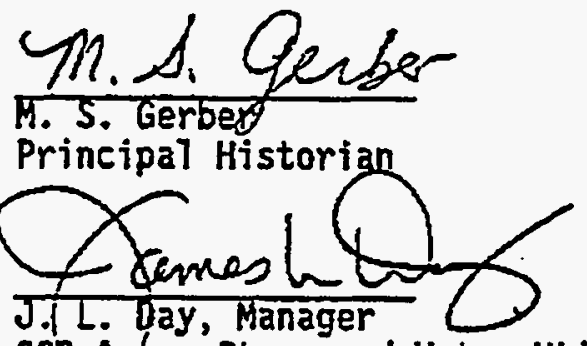

200 Areas Steam and Water UtiTities

ICF Raiser Hanford Company

RL - M. J. Elsen

D. H. Lloyd

A. H. Wirkkaia ( $\boldsymbol{H} / 0$ enclosures)

BHI - T. E. Marceau

CTUIR - J. Van Peit

PNNL - G. T. Kirk (W/0 enclosures)

P. R. Nickens 
Sitc Nanie Historic $\overline{\text { Power House }}$

CummonSteam Plan

Field Recurder

Address P.O. Isox 550

City/Sulte/Zip Code Richland, WA 99352

Stans

a Survey/hnentury

$\square$ National Register Rincha

$\exists$ Stuce Register

$\square$ Determired Eligible

$\square$ Determined Not Eligible

$\square$ Orher (HABS, BAER, NHL)

C. Local Devignition

Clessification $\square$ Diatria $\square$ Site Bujlding UStructure $\square$ Object

District Status $\Pi \mathrm{NR}$ U.SR $\square$ LR $\square$ INV

Contributing $\square$ Non-Contributing $\square$

DistrictThematic Nomination Nume

DESCRIPTION SECTION

Materiaks \& Features/stroctural types

\section{PHOTOGRAPHY}

Photography Neg. No. 94070043-27an

(Roll No. \& Prame No.)

- View of West fice and roor

Dato

994

Bullding Type Industry

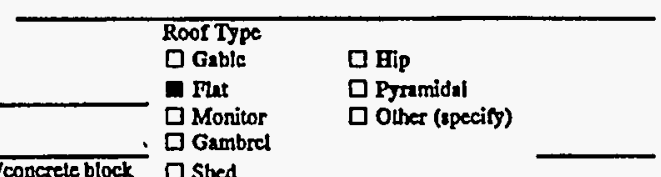

Plan Rectangular

Gambra

Structural System Steel framelconcrete block 1 Shed

Cladding (Exterior Wall Surfices)

$\square \log$

D. Wood Shake

13 Horizontal Wood Siding D Ruxtic/Drop
$\supset$ Clupbount

$\square$ Wood Shingle

$\sqcup$ Composition

$\square$ Board and Banten

П Tru/Built-Up

C. Vertical Bourd

$\square$ Asbestos/Asphalt

1) Brick

G Stone

$\square$ Stucso

$\square$ Terra Cors

- ConcreteiConctele Block

$\square$ ViayUAlumimum Siding

口Metal (specify)

M Metal (speciry)

Prechs concretedbuilt-up

Other (specify) gravel surface

(Include detailed description in

Foundation

rowg

$\square$ Post \& Pier

口 Greek.Revival
$\square$ Gothic Revival

Li Iralizante

Cily/Counly/Zip Code Richland, WNBenton County/99352

Twp. Range Section W Section W' Section

Tux No./Parcel No

UTM References Zone $11 \longrightarrow$ Easting Sec altached Nosthing See attached

PlatBloct/Lot

Supplemental Maps

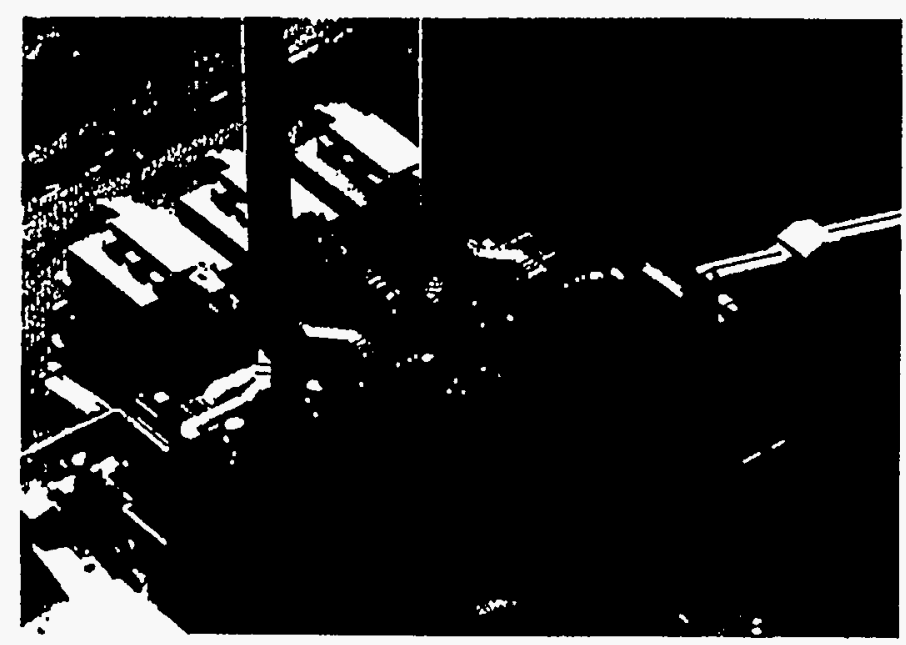

Figh Stgles/rorms (check one or mose of the following)

C Romanesque Revival

C Slick Style

$\square$ Queen Anne

T) Shingle Style

$\square$ Brick

$\square$ Not visible

$\square$ Block

$\square$ Youred Description of Physical Appearawe

Colonjal Revival

$\checkmark$ Chicago/Commercial Styte

$\square$ American Foursquare

$\square$ Mission Revival

Vernzeular Bouse Typo

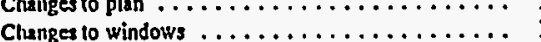

Changes to original cladding

प Gable front

0 Gable front and wing

Other (specify)

$\begin{array}{ccc}\text { Slight, } & \text { Moderate } & \text { Extensive } \\ U & \square & \Xi \\ \square & \square & \square \\ \square & \square & \square \\ \square & \square & \sqcup \\ \Xi & \square & \square\end{array}$

co side gable

- Spanish Colonill Revival/Medilerranean 口 Ludar Revival

口 Craftsman/Arts \& Crafts

D Bungalow

0 Prairic Style

a An Deco/Art Modemo

Rustic Style

0 International Style

$\square$ Northwest Sigle

Residential Vemacular (see below)

Other (upecity) Industral vernecular

9 Cross gable

D. Pyramidal/Hipped

0 Orher (specify) 


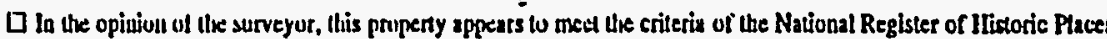

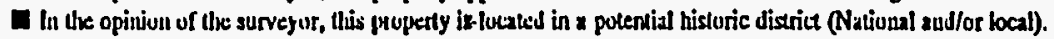

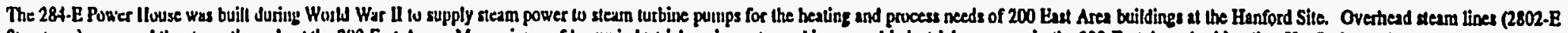

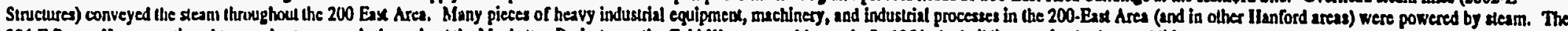

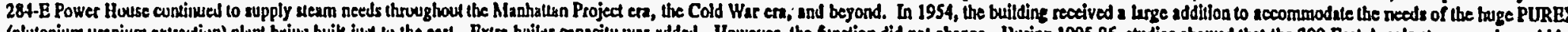

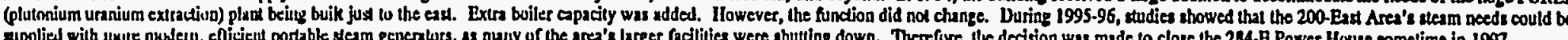

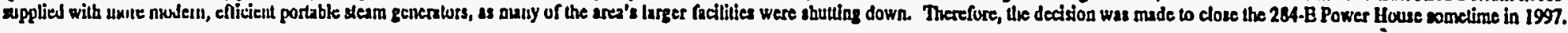

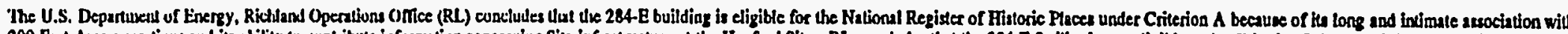

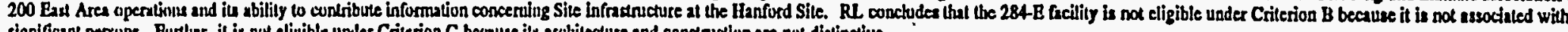

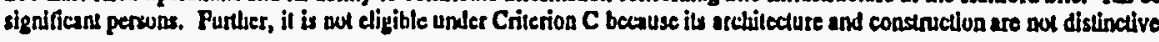

\section{Descriplian of thydsul Appearauce}

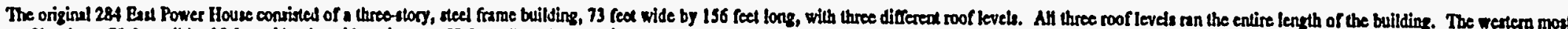

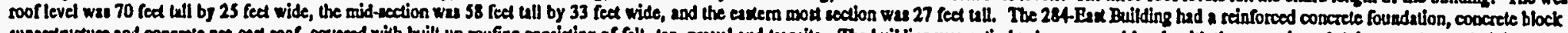

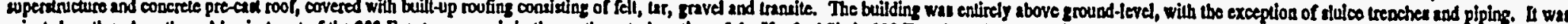

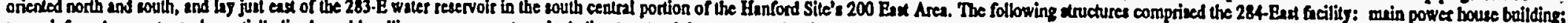

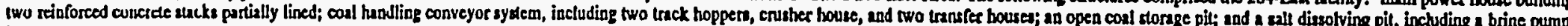
buute.

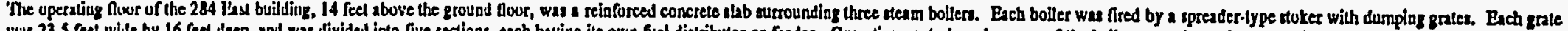

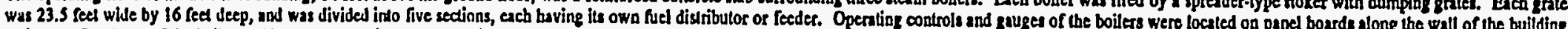

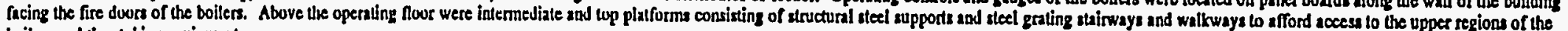
builers and the sutillg equipsicn.

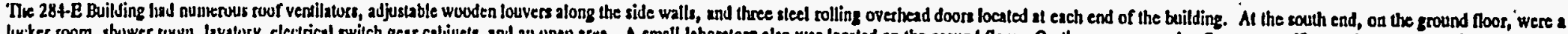

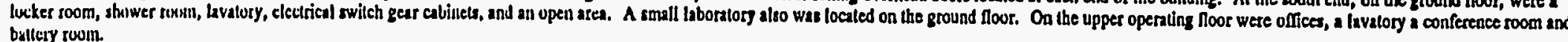

The boilers were cumbected to two reinfurced cuncrete-Jined stscks by means of four outside steel breechings, two breeclungs running to each atack. The stacks are 250 feet tall and are 23 feet at the base, upering to nine feet

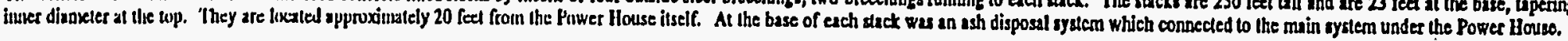

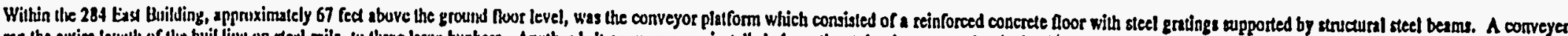

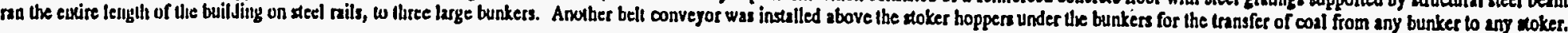




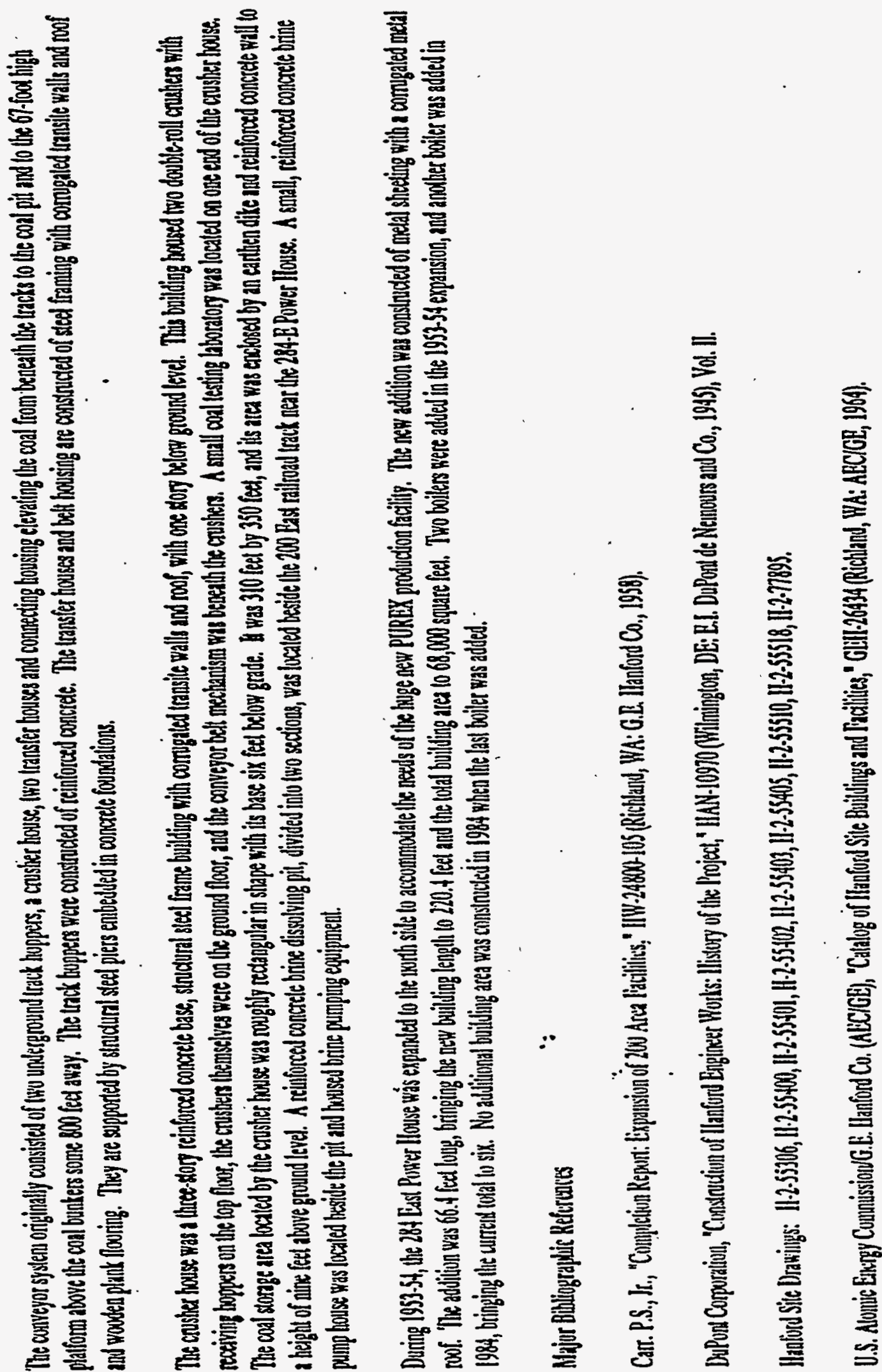


200E, TM: COOREINFEES

N

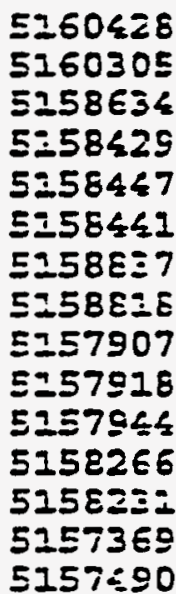

$\mathbf{E}$

\begin{tabular}{|c|}
\hline $\begin{array}{l}304=26 \\
30725 \\
307262 \\
3076=3 \\
307614 \\
307750 \\
306025 \\
308480 \\
308439 \\
308267 \\
307552 \\
307606 \\
307165 \\
307129 \\
304204\end{array}$ \\
\hline
\end{tabular}

200 EAST PERIMETER FENCE

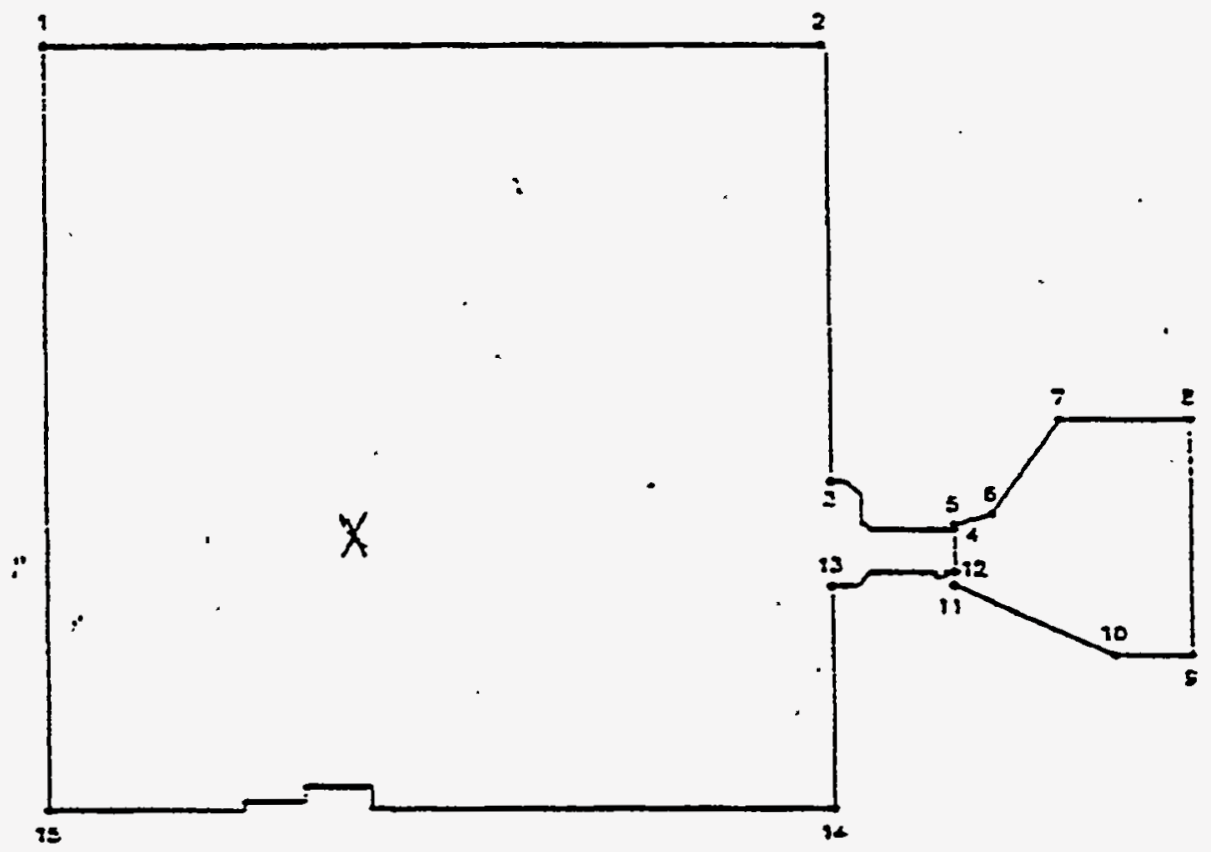




\section{(W) Hestinghouse}

P.O. Bax 1970 Fichland, Wh 99352

May 17,'1996

9651963

Mr. J. E. Rasmussen, Director

Environmental Assurance,

Permits, and Policy Division

U.S. Departrent of Energy

Richland, Washington 99352

Dear Mr. Rasmussen:

DEMOLITION OF BUILDING 384, HANFORD SITE (HCRC \#96-300-025)

A Cultural Resources review was conducted by Hestinghouse Hanford Company (WHC) at the request of ICF Kaiser Hanford Company (ICF KH) on the demolition of the 384 Power House on the Hanford Site. A literature and records search, as well as oral history contacts, reveal that the 384 Power House was constructed in World War II and has served as a steam power generating facility since that time. The 384 Building was found to be a contributing structure to a potential Hanford Site Historic District, both by the HHC Historian and by the Hanford Site Cuitural Resources Task Group.

A need has arisen to demolish the 384 Building as part of cost saving and efficiency measures in the Hanford Site cleanup mission. In fiscal year (FY) 1997, the 384 Building will be deactivated. Activities at that time will consist of isolating equipment from power sources, shutting off and diverting water supplies, cleaning out residual debris, and housekeeping measures. Demolition of the facility will take place in FY 1998. However, it is necessary to complete the historical and other reviews for the 384 Building that are required by the National Environmental Policy Act (NEPA) in the near term, because the NEPA-driven reviews are being combined with similar documentation for the other two Hanford Site power plants (the 284-H and 284-E Buildings) in order to achieve cost savings. Timely completion is required so as not to delay demolition of the 284-W Building.

Therefore, HHC proposes at this time that historical mitigation of the 384 Building be completed in the future in conformance with the Site-wide Programatic Agreement for the built environment of the Hanford Site, currently being negotiated between the U.S. Department of Energy, Richland Operations Office and the State Historic Preservation Office (SHPO). It is the conclusion of the WHC Cultural Resources office that the future historical documentation that is planned will be sufficient to mitigate any adverse effects that may be caused by the demolition of the 384 Buł1ding. 
Mr. J. E. Rasmussen

Page 2

9651963

May 17, 1996

We request that you seek concurrence from the SHPO and any necessary concurring agencies on plans to deactivate and demolish the 384 structure with no historical documentation effort at this time. If any archaeological or additional historical resources are discovered during deactivation activities, work will be halted and your office informed immediate?y.

Very truty yours,

ARectot

D. B. Cartme17, Director Transition Programs

Transition Projects

dc

CONCURRENCE:
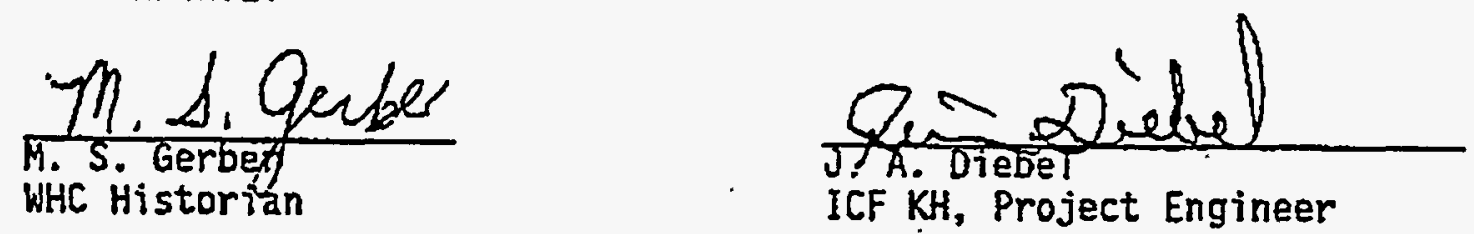

RL - M. J. ETSEn

D. W. Lioyd

A. H. Wirkkala

BHI - T. E. Marceau

PNNL - G. T. Kirk

P. R. Nickens 


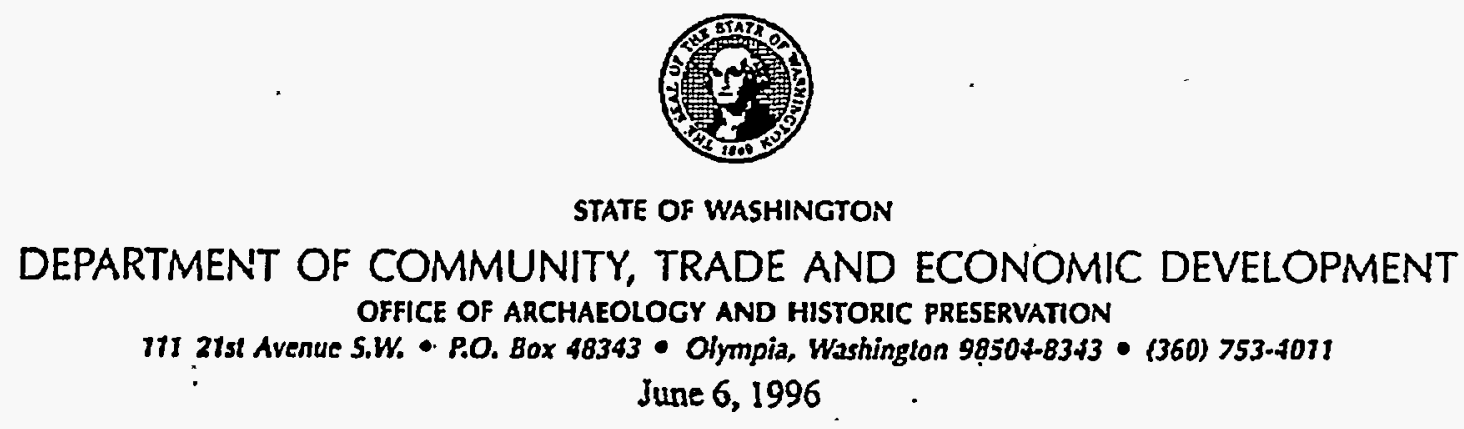

Mr. Dee W. Lloyd, Manager

Cultural Resources Program

Department of Energy

Richland Operations Office

- Post Office Box 550 Mailstop A5-15

Richland, Washington 99352

Log: 060496-09-DOE

Re: Demolition of Buildings $2710-W$ and 384

Dear Mr. Lloyd:

Thank you for contacting the Washington State Office of Archaeology and Historic Preservation (OAHP) regarding the above referenced actions. From your letter, I understand that the Department of Energy (DOE) proposes to demolish Buildings 2710-W and 384 in the 200 and 300 Areas respectively at the Hanford Site (HCRC \# 96-200-047 and 96-300-025).

In response, I concur that Building 384 steam power generating facility is a contributing structure to the Hanford Site National Register eligible Historic District. Therefore, it is my opinion that demolition of Building 384 is an adverse effect to the historic district. Hence, 1 recommend mitigation of Building 384 demolition in conformance with the Site-wide Programmatic Agreement for the built environment of the Hanford Site. Similarly, I concur that the 2710-W is a non-contributing property to the historic district according to the recommendations of the WHC Historian and the Hanford Site Cultural Resources Task Group.

Thank you for the opportunity to comment. Should you have any questions, please feel free to contact me at (360) 753-9116.

GAG:tjt

\section{PECEIVED}

JUN 101996

DOE Fis/CCC

196 -nRP-079
Sincerely,

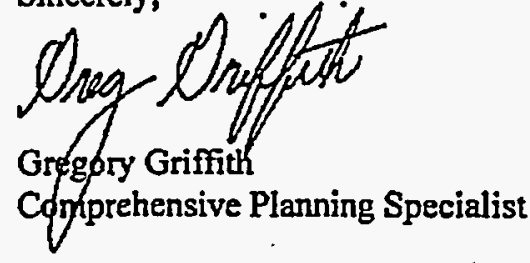


FINDING OF NO SIGNIFICANT IMPACT FOR THE

SALVAGE/DEMOLITION

OF

200 WEST AREA, 200 EAST AREA, AND 300 AREA STEAM PLANTS

HANFORD SITE, RICHLAND, WASHINGTON U.S. DEPARTMENT OF ENERGY

OCTOBER 1996 


\section{AGENCY: U.S. Department of Energy}

\section{ACTION: Finding of No Significant Impact}

SUMMARY: The U.S. Department of Energy (DOE) has prepared an Environmental Assessment (EA), DOE/EA-1177, to assess environmental impacts associated with the salvage and demolition of the 200 West Area, 200 East Area, and 300 Area Steam Plants and their associated steam distribution piping, equipment, and ancillary facilities at the Hanford Site, Richland, Washington.

It is proposed that all materials, wastes, and equipment be salvaged and recycled where feasible. The existing coal storage yards of each steam plant would serve as lay down yards to store equipment and material during salvaging activities. Foundations and concrete footings would be removed in order to return the areas to ground level for potential reuse. Waste minimization practices would be in place to keep wastes at a minimum.

Based on the analysis in the EA, the DOE has determined that the proposed action is not a major federal action significantly affecting the quality of the human environment within the meaning of the National Environmental Policy Act of 1969 (NEPA), 42 U.S.C. 4321, et seq. Therefore, the preparation of an Environmental Impact Statement (EIS) is not required.

\section{ADDRESSES AND FURTHER INFORMATION}

Single copies of the EA and further information about the proposed action are available from:

W. A. Rutherford, Acting Director

Site Infrastructure Division

U.S. Department of Energy

Richland Operations Office

Richland, Washington 99352

(509) 376-7597 
For further information regarding the DOE NEPA Process, contact:

Carol M. Borgstrom, Director

Office of NEPA Oversight

U.S. Department of Energy

1000 Independence Avenue, S.W.

Washington, D.C. 20585

(202) $586-4600$ or $(800) 472-2756$

PURPOSE AND NEED: The U.S. Department of Energy (DOE) needs to reduce costs of future surveillance and maintenance for the 200 West Area Steam Plant, and avoid future surveillance and maintenance costs for the 200 East Area and 300 Area Steam Plants.

BACKGROUND: The transition of the Hanford Site mission from defense production to a restoration mission has reduced the large demand for steam required to support defense operations. The 200 West Area Steam Plant was shut down in fiscal year 1995 and is currently in surveillance and maintenance awaiting decommissioning. The 200 East Area and 300 Area Steam Plants are currently in operation and are expected to be shut down in the near future. The costs for access controls and surveillance and maintenance of the steam plants would escalate over time.

PROPOSED ACTION: The DOE proposes to salvage and demolish the steam plants in the 200 West Area, 200 East Area, and 300 Area with their associated steam distribution piping, equipment, and ancillary facilities. Activities would include salvaging and recycling of all materials and equipment where feasible, in keeping with waste minimization principles. Existing coal storage yards would serve as lay down yards to store equipment and material during salvaging activities. Foundations and concrete footings would be removed in order to return the areas to ground level for potential reuse.

ALTERNATIVES CONSIDERED: The EA discussed several alternatives to reduce surveillance and maintenance costs for the 200 West Area, 200 East Area, and 300 Area Steam Plants, as well as the No Action Alternative.

No-Action Alternative. This alternative would keep the 200 West Area Steam Plant in surveillance and maintenance indefinitely. Following the shutdown of the 200 East Area and 300 Area Steam Plants, there would be no isolation activities and no decommissioning activities for those facilities. The costs of maintaining the buildings would increase over time. This alternative was not considered a reasonable alternative.

Alternative Surveillance and Maintenance. This alternative would keep the 200 West Area Steam Plant in surveillance and maintenance mode indefinitely, and the 200 East Area and 300 Area Steam Plants would be put into surveillance and maintenance mode indefinitely after deactivation activities. Costs of maintaining the buildings would increase over time. This alternative was not considered a reasonable alternative.

Alternative Uses. This alternative would reuse the three steam plants for other activities. At this time, no foreseeable reuse has been identified.

ENVIRONMENTAL IMPACTS: All areas involved in the proposed action are previously disturbed areas. No Federally or State listed, proposed or candidate, threatened, endangered species are expected to be effected by the proposed action. However, to avoid adverse impacts to cliff swallows, demolition of the coal ramp building in the 200 West Area Steam 
Plant would be undertaken outside the nesting season that extends from April 1 to July 30. It is planned during the salvage/demolition phase to remove all foundation and concrete footings and the steam distribution system poles. If any hazardous or radioactive contamination is found in the soils during excavation, the contamination would be covered with clean soil and left in place awaiting remediation of the Operable Unit, or otherwise dealt with in a manner acceptable to the relevant regulatory agency. All voids that would occur during this phase would be backfilled. Because the amount of soil disturbance would be minimal and temporary, anticipated impacts to the environment are not expected to be consequential.

DOE and the State Historical Preservation Officer (SHPO) concur that the proposed action would have no adverse effect on the Hanford Site Historic District, of which the 284-West Powerhouse is part. The SHPO has concurred with DOE that the 384 Powerhouse is a contributing structure to the Hanford Site Historic District. Since the Programmatic Agreement between the DOE, SHPO, and the Advisory Council on Historic Preservation allows mitigation of buildings through preparation of an Historic Property Inventory Form (HPIF), it is expected that there would be no adverse effects on the cultural resources of the proposed action.

It is expected that only nonhazardous solid waste would be generated during the salvage/demolition phase of the proposed action. Any hazardous substances or materials that might be discovered later in the buildings would be managed in accordance with applicable federal and state regulations. Waste resulting from the proposed action is expected to be minimal compared to annual Hanford Site waste generation. The proposed action would not release any particulate matter, thermal releases, or gaseous discharges in significant amounts. Therefore, these impacts to the environment are expected to be small.

\section{Accident Impacts}

The only reasonably foreseeable accidents under the proposed action would be typical construction accidents associated with salvage and demolition activities, including blasting, and subsequent backfilling activities. Areas would be roped off and cleared of personnel prior to any blasting. Areas affected by blasting would be restricted to the building sites. Personnel handling recycle and salvage/demolition activities would follow approved safety procedures. Typical construction hazards would be present, however the risk of a severe accident is small. 
Socioeconomic Impacts

Only small numbers of workers would be involved at any one time. Therefore, no socioeconomic impacts are expected from the proposed action.

Environmental Justice

Executive Order 12898, Federal Actions to Address Environmental Justice in Minority

Populations and Low-Income Populations, requires that federal agencies identify and address, as appropriate, disproportionately high and adverse human health or environmental effects of their programs and activities on minority and low-income populations. With respect to Executive Order 12898 regarding environmental justice, distributions of minority and low income population groups have been identified for the Hanford Site. The analysis of the impacts in this EA indicates that there would be minimal impacts to both the offsite population and potential workforce by implementing the proposed action, because the entire proposed action would occur on the Hanford Site and the offsite environmental impacts from the proposed action analyzed in this EA are expected to be minimal. Therefore, it is not expected that there would be any disproportionate impacts to any minority or low-income portion of the community.

\section{Cumulative Impacts}

Waste generation and disposal resulting from the proposed action are not expected to be considerable and would not substantially effect any associated operations or disposal sites; therefore, the proposed action is not expected to result in any cumulatively significant impacts.

DETERMINATION: Based on the analysis in the EA; and in the absence of any public comments, I conclude that the proposed Salvage/Demolition of the 200 West Area, 200 East Area, and 300 Area Steam Plants at the Hanford Site, Richland, Washington does not constitute a major federal action significantly affecting the quality of the human environment within the meaning of NEPA. Therefore, an EIS for the proposed action is not required.

Issued at Richland, Washington, this 21st day of October 1996.

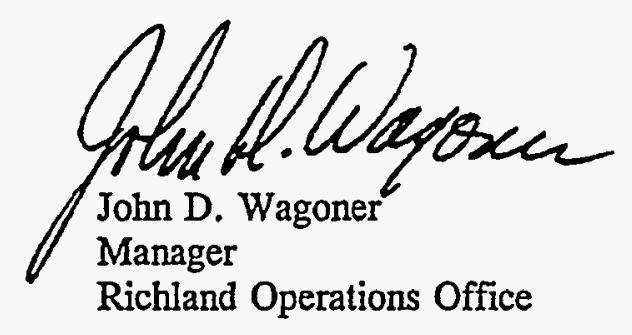

